\title{
Seismic performance evaluation of regular and irregular composite moment resisting frames
}

\author{
Serkan Etlia,b* (D), Esra Mete Güneyisi ${ }^{\mathrm{b}}$ (D) \\ a Department of Civil Engineering, Munzur University, 62000, Tunceli, Turkey. E-mail: serkanetli@munzur.edu.tr \\ b Department of Civil Engineering, Gaziantep University, 27310, Gaziantep, Turkey. E-mail: eguneyisi@gantep.edu.tr \\ * Corresponding author
}

https://doi.org/10.1590/1679-78255969

\begin{abstract}
In this study, the seismic behavior of regular and irregular composite moment resisting frame (CMRF) buildings was investigated. To this aim, 5, 8, 10, 13 and 15-story CMRFs having concrete filled steel tube columns and composite beams were designed at high ductility level and their performances were evaluated comparatively. The case study CMRF structures were categorized into two groups as regular and irregular in elevation. Examined irregular structures have setbacks in different story levels. During the design and performance analysis, SeismoStruct software was employed. Nonlinear static pushover and incremental dynamic analyses were used in the seismic performance assessment. The uniform and triangular load distributions were considered in the pushover analysis while a total of 22 earthquake acceleration records were utilized in the dynamic analysis. The variation in the lateral response, global yielding value, interstory drift, behavior factor, inherent strength factor, overstrength factor, and ductility factor were examined for the regular and irregular CMRF structures. It was observed that the regular CMRFs were more consistent with the design assumptions as compared to the irregular ones. Moreover, the former exhibited more uniform non-elastic demands over the building height according to the results of the incremental dynamic analysis. Under the seismic scenario adopted, all the building types yielded higher values of the behavior factor complied with the limits available in the code.
\end{abstract}

\section{Keywords}

Behavior factor; Composite frame; Concrete filled steel tube; Incremental dynamic analysis; Nonlinear pushover analysis.

\section{Graphical Abstract}

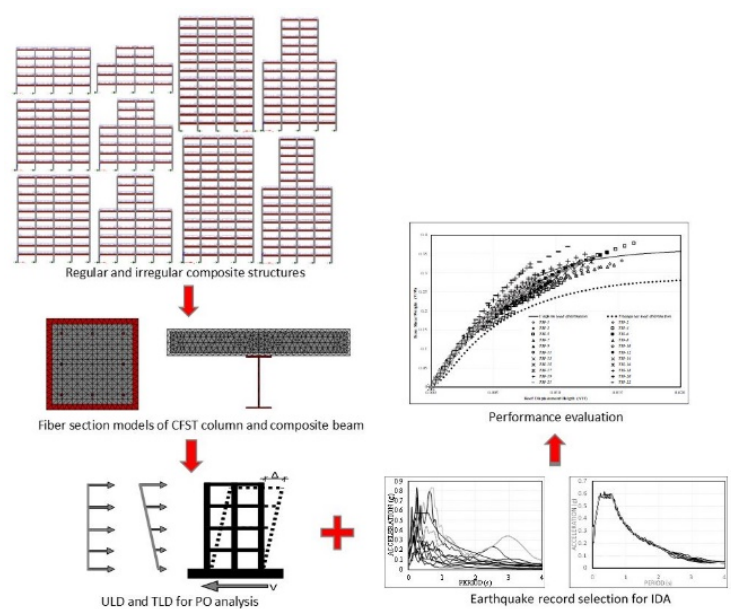




\section{INTRODUCTION}

Composite steel and concrete building systems are widely used in areas with high seismic risk such as in North America and Japan. Due to its cost effectiveness and improved structural performance compared to steel or reinforced concrete structures, it is also becoming popular in earthquake-prone areas in Europe (Di Sarno and Pecce 2007). The ductility of composite structures is mainly provided by composite columns and beams designed in line with the code requirement. Structures with concrete-filled steel tube (CFST) elements are increasingly used in high-rise buildings, bridges and other industrial buildings due to their excellent seismic performances in terms of high strength, ductility and energy absorption. There have been extensive theoretical and experimental studies on the behavior of composite elements in the literature (Shams and Saadeghvaziri 1997; Shanmugam and Lakshmi 2001; Li et al. 2019, 2020). In addition, the composite interaction between steel and concrete is difficult to model appropriately (Thai and Kim 2011). Numerous composite beam and column models have been developed by the researchers. For example, Tomii and Kenji (1979) presented an analytical model for the elastic-plastic analysis of CFST column-beam. To consider the limiting effects, the stress-strain relationships were proposed for the wrapped concrete in the tube member. Hajjar et al. (1998) proposed a fiber-based distributed plastic finite element model for the nonlinear non-elastic analysis of CFST columnbeam. Moreover, in the literature, there have been some investigations on the structural response of CFST included frames such as steel beam connected to square CFST column composite frames (Wang et al. 2009) and frames with circular CFST columns to steel beams (Han et al. 2011). They also considered the panel zone and connection effects on the models in the parametric verification of their experimental works. In another study by Wang et al. (2017), the composite frames with square or circular CFST columns and steel-concrete composite beams with steel-bars truss deck were tested and their analysis results were examined in terms of various response parameters. Researchers studied on the pseudo-dynamic testing and analytical modeling of blind-bolted CFST frames with buckling-restrained braces (Shams and Saadeghvaziri 1997; Shanmugam and Lakshmi 2001; Li et al. 2019, 2020). Moreover, the seismic response of rectangular CFST column composite frames with the inclusion of the slab was evaluated experimentally and finite element modeling was performed to simulate the tested composite frames (Jianguo et al. 2012).

Among the types of the structures, the buildings with setback show some irregular configurations in elevation. Therefore, for their seismic capacities, much care in the design stage is required. It usually causes vertical irregularities due to sudden reductions in plan dimensions along the elevation of the setback structures. Vertical irregularities may affect the seismic performance of the structures depending on the limit-state or level of the seismic intensity considered (Michalis et al. 2006). Hence, most of the seismic codes for the design of structures under the earthquake loading contain some limiting criteria to prevent the discontinuity problem in these structures. Recent researches on determining the seismic performance of vertically irregular structures indicate that the limitations of earthquake design in such buildings should be defined by considering the following items: (i) expected performance target, (ii) seismic intensity level, (iii) different positions of irregularities on height, (iv) number of vertically irregular stories, and (v) movement of geometric vertical irregularities combined with torsional irregularities (Karavasilis et al. 2008; Le-Trung et al. 2012; Pirizadeh and Shakib 2013; Shakib and Pirizadeh 2013).

Indeed, the past earthquake experiences have shown that irregular structures exhibit inadequate behavior under seismic loads and suffer more damage. Therefore, some studies in the literature have discussed the adequacy of the design criteria and procedures of simplified traditional seismic design codes applied in such irregular buildings. For example, Duan and Chandler (1995) examined the seismic response of a setback framework structure class, taking into account the inelastic behavior of the structural elements, but considering a representative setback frame model. They stated that both static and modal spectral analysis were insufficient to predict and prevent damage concentration in the members close to the level of irregularity. Tena-Colunga (2004) studied the undesirable concentration of plastic deformation around the irregularity line by investigating the seismic response of the irregular structure of two types of slender stepped special reinforced concrete moment resisting frame systems designed to fulfill the seismic requirements of Mexican law. Karavasilis et al. (2008) also presented a comprehensive parametric study on the non-elastic seismic response of plane steel moment resisting frames designed according to European codes. In the scope of their study, the frames were subjected to 30 regular earthquake ground motions scaled to different seismic intensities to drive different boundary conditions. The results of the statistical analysis of the generated response database were examined by considering the number of stories, beam-column strength ratio, geometric irregularity, and limit state status. It was found that the height-width distribution and inelastic deformation demands were intensely affected. In another study by Pirizadeh and Shakib (2019), a reliability based technique was used for evaluating and enhancing the earthquake response of mid-rise steel moment resisting framed building with setback. The low seismic performance of such buildings has been linked to the combined effect of structural irregularities, non-uniform mass, stiffness and force distribution 
along the height of the setback frames. Moreover, one or two sided setback configurations with symmetric or asymmetric around the vertical axis of the structure are also a key factor on the performance assessment (Karavasilis et al. 2008).

\section{RESEARCH SIGNIFICANCE}

Due to various architectural requirements, setback-type irregular structures, which are formed by the sudden reduction of the floor area after certain building levels, are often preferred. On the other hand, the increase in damage probabilities observed in such reinforced concrete or steel moment resisting framed structures after severe seismic events provides strong evidence that the setback included buildings may be inadequate. Therefore, apart from the existing studies, in this investigation, it is aimed to evaluate the effect of the setbacks in the composite moment resisting frame (CMRF) buildings considering the nonlinear behavior of the structural members. For this reason, two groups of structures, 5, 8, 10, 13 and 15-storey CMRF buildings having composite beams and CFST columns were designed seismically by using Eurocode-8 (2004) norms as regular and irregular with various setbacks. In the finite element modeling and analysis, SeismoStruct software was utilized. Firstly, the finite element model developed in this study was verified through the comparison of the experimental results of composite frames under lateral loading given in the literature. Then, a parametric study was conducted in which the performances of the case study composite structures with and without setbacks were studied by using pushover and incremental dynamic analyses. The uniform and triangular load distributions in the pushover analysis were used while a total of 22 different ground motion records were employed in the dynamic analysis. Various parameters such as the lateral behavior, global yielding point, behavior factor, inherent strength factor, overstrength factor, and ductility factor were evaluated. In addition, the interstory drift response of both the regular and irregular CMRF structures were assessed considering the design basis earthquake (DBE) and maximum considered earthquake (MCE) hazard levels. Based on these parameters, the influence of setback irregularities on the seismic response of the CMRF structures were discussed comparatively.

\section{DETAILS OF THE STUDY}

In this study, the behavior of composite moment resisting frames (CMRFs) with concrete filled steel tube (CFST) columns and composite beams were investigated. They were designed as regular and irregular structures and then compared in terms of basic shear force and displacement responses considering the static and dynamic effects. In fact, this comparison was made for the code-designed structures under two different cases. One is an irregular case including symmetric two-sided setbacks and the other is a regular case. To this, a total of $10 \mathrm{CMRF}$ structures having various story levels of 5 to 15 were employed. A half of them were modeled as regular structures and the remains were as irregular structures. The plan features of the regular and irregular buildings are shown in Figures 1 and 2, respectively. In Figure 3 , the elevation views of all frames are given. As seen from the figure, the setback occurred on the 3rd, 5th, 6th, 8th and 9 th levels for the irregular buildings having different heights.

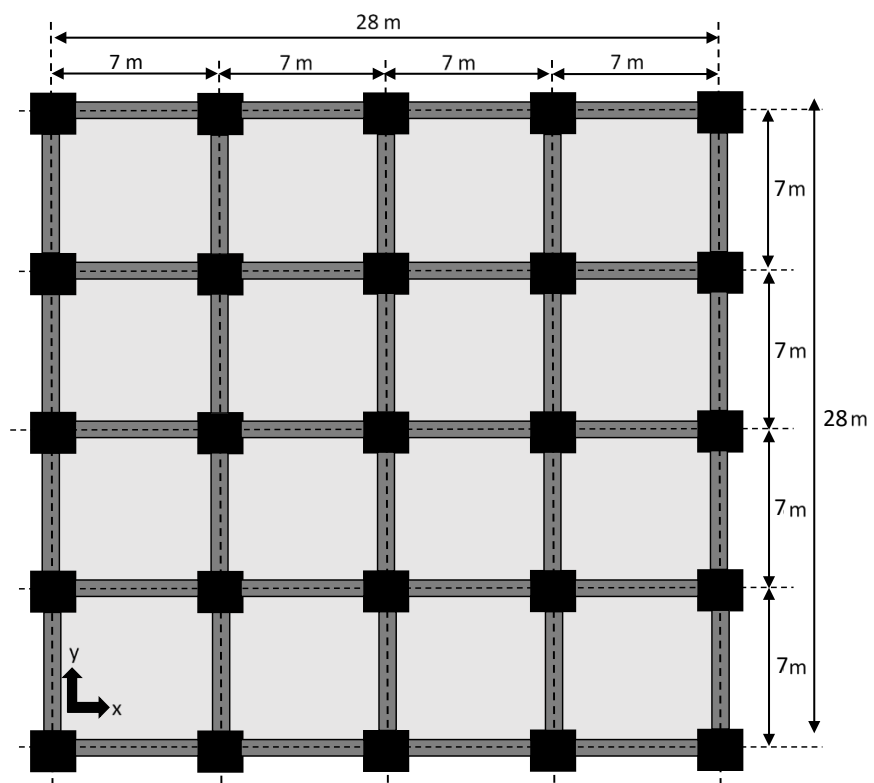

Figure 1 Floor plan of the regular buildings. 


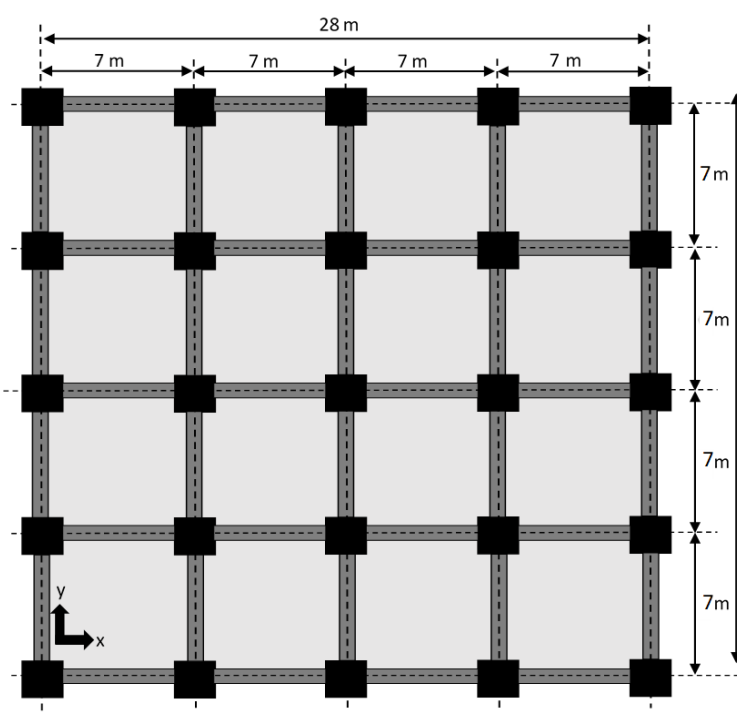

a)

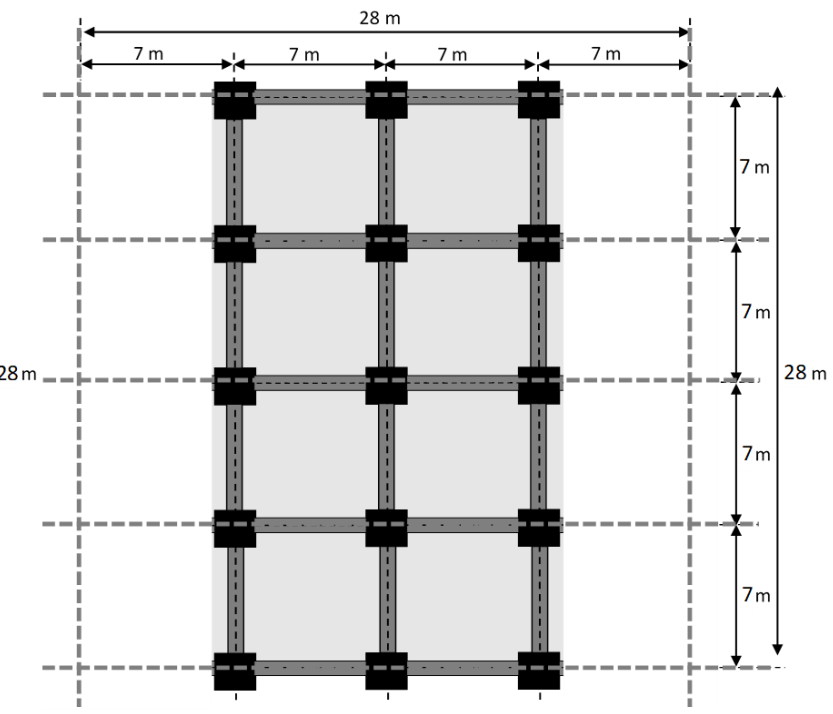

b)

Figure 2 Floor plan of the irregular building for: a) regular and b) irregular parts in elevation.
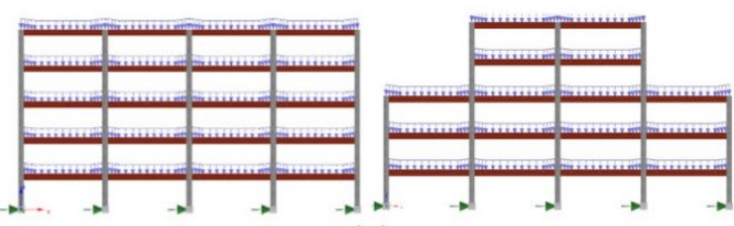

(a)

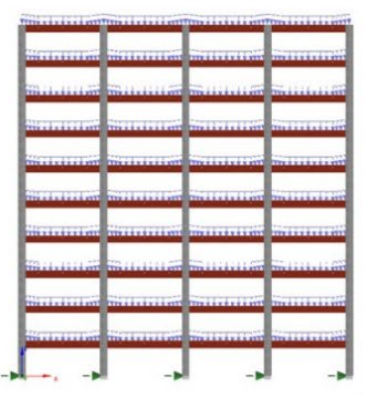

(c)

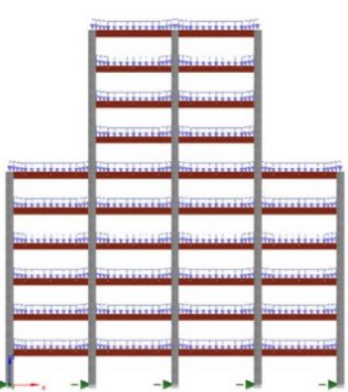

c)

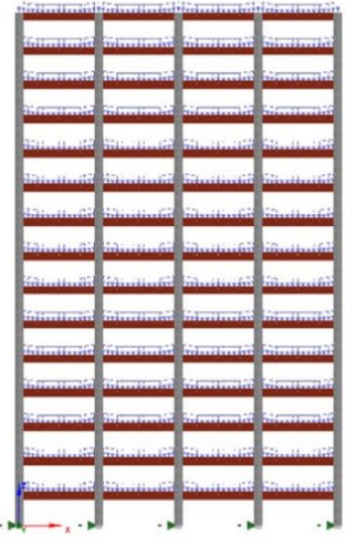

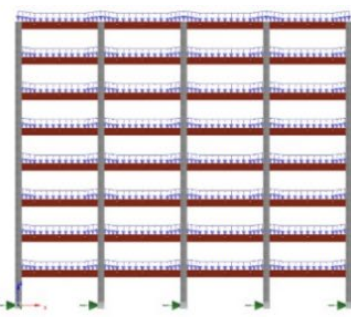

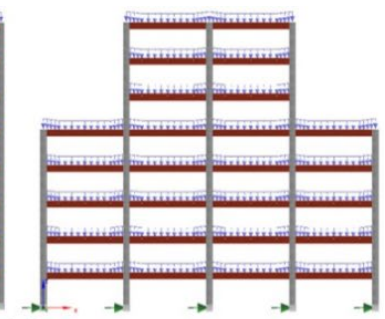

(b)
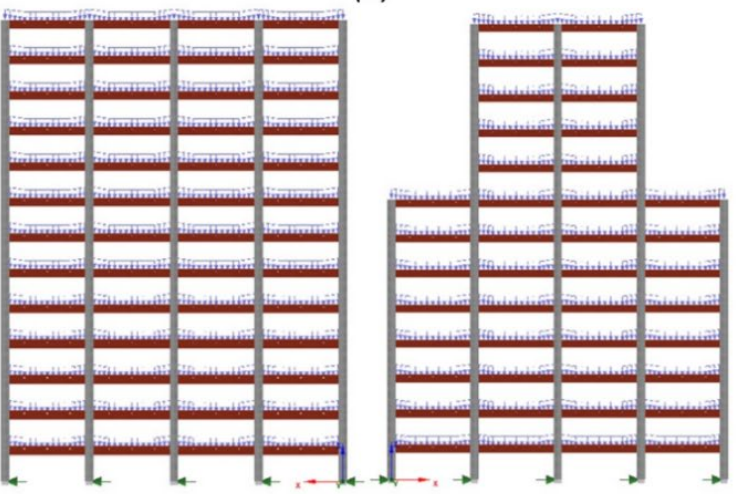

(d)

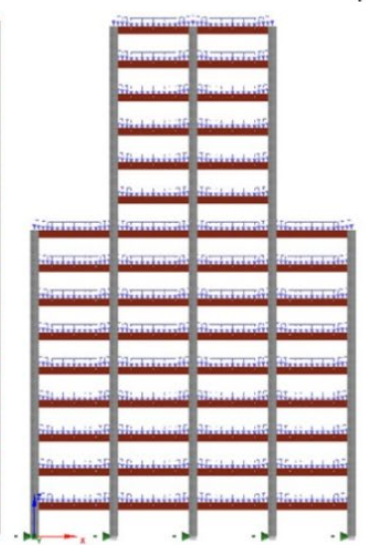

(e)

Figure 3 Regular and irregular frame elevations for different stories a) 5, b) 8, c) 10, d) 13, and e) 15 . 
In the plan, the columns were placed at $7 \mathrm{~m}$ intervals in both $\mathrm{x}$ - and y-directions. The CFST columns with square hollow section (SHS) and composite beams constructed with steel IPE profile and slab were considered in the design of the structures. The analyses were taken into account in one-direction of the building and were performed on 2D frames on the strip in the middle of the building. The flooring height is $18 \mathrm{~cm}$. When the wall load of $3 \mathrm{kN} / \mathrm{m}$ is used in the beams of the structure, the floor is considered to finish the dead loads and the moving loads are 2 and $3 \mathrm{kN} / \mathrm{m}^{2}$, respectively. Moreover, a symmetrical two-sided setback configuration was examined for each case study structure. Additionally, the plan geometry of the irregular buildings was the same as the first group up to the level where the plan was narrowed, and then the structural plan was altered as shown in Figure 2. These setback configurations are defined considering two percentages, $\mathrm{RA}$ and $\mathrm{RH}$. RA (area setback rate) is defined as the relative area of the structure to the base, and $\mathrm{RH}$ (height setback rate) is described as the relative height of the structure according to Shahrooz and Moehle (2007). As Figure 3 shows, the setback ratios considered are $\mathrm{RA}=0.5$, and $\mathrm{RH}=2 / 3,3 / 5$, and $5 / 8$. The buildings of the two groups were designed as 5, 8, 10, 13 and 15 story steel-concrete composite office buildings.

CMRF models are designed using Eurocodes 3, 4 and 8 (EN 1993-1-1 2005; EN 1994-1-1 2004; EN 1998-1 2004). The design was developed in two stages. In the first phase of the design, the material and cross-sectional properties of the composite beams and columns of all models were selected under the gravity loads. Then, in the second stage, the results of the behavior of CMRFs under the earthquake effects were evaluated and the design values were checked accordingly. Earthquake analysis was performed by the modal analysis method which was accepted in most of the design codes. For modal analysis according to Eurocode-8 (EN 1998-1, 2004), the parameters used to obtain the earthquake spectra were Type-I spectra, Ground C, peak ground acceleration (PGA) $0.2 \mathrm{~g}$ and damping factor $\xi=5 \%$. In addition, two different behavior factors have been used in the design process, one for regular and the other for irregular structures. The basic value of the selected behavior factor of both groups is equal to 6.5. For irregular structures, it should be multiplied by 0.8 as per Eurocode-8 (EN 1998-1, 2004), equal to $6.5 \times 0.8=5.2$.

In the design stage, after the capacity of the column and beam sections were checked according to seismic design specifications of CMRFs, the structural stability and drift criteria of CMRFs were evaluated under design seismic loads. Second-order effect controlled with sensitivity coefficient and symbolized with $\theta$ and it is limited as 0.2 for this study. After the $\theta$ value passes 0.1 , it is taken into consideration of the seismic design via simplified formulation given in Eurocode-8 (EN 1998-1, 2004). Moreover, this value is the limit of the calculation for taking into consideration of second order effect with the elastic analysis, according to Eurocode-8 (EN 1998-1, 2004). The $\psi$ value is used to reflect the behavior of non-structural elements in the structure design. This value is given in $0.5 \%, 0.75 \%$ and $1.0 \%$ in Eurocode- 8 (EN 1998-1, 2004) for the structural systems using brittle, ductile and non-structural or insulated elements, respectively. In the design of the structures within the scope of this study, $\psi$ value was used as $0.75 \%$. The cross-sectional properties of the structural elements used in the design and the classes of materials used in these elements are given in Table 1. The grade of the structural steel was selected as S235 and the concrete class C30 was used in all structures. Both regular and irregular structures in elevation were designed as high ductility level (DCH) system. In Table 2, the modal mass participation factors and the natural vibration periods of the models are provided.

Table 1 Member property and behavior factor of the structures.

\begin{tabular}{|c|c|c|c|c|c|}
\hline Buildings & Beam & Column (mm) & Concrete & Steel & $q$ \\
\hline 5STRY/RGLR & IPE 360 & $450 \times 28$ & $\mathrm{C} 30$ & S235 & 6.5 \\
\hline 5STRY/IRRGLR & IPE 360 & $450 \times 25$ & & & 5.2 \\
\hline 8STRY/RGLR & IPE 450 & $550 \times 36$ & & & 6.5 \\
\hline 8STRY/IRRGLR & IPE 400 & $550 \times 36$ & & & 5.2 \\
\hline 10STRY/RGLR & IPE 450 & $650 \times 50$ & & & 6.5 \\
\hline 10STRY/IRRGLR & IPE 400 & $650 \times 40$ & & & 5.2 \\
\hline 13STRY/RGLR & IPE 550 & $700 \times 50$ & & & 6.5 \\
\hline 13STRY/IRRGLR & IPE 500 & $700 \times 50$ & & & 5.2 \\
\hline 15STRY/RGLR & IPE 550 & $750 \times 55$ & & & 6.5 \\
\hline 15STRY/IRRGLR & IPE 500 & $750 \times 55$ & & & 5.2 \\
\hline
\end{tabular}


Table 2 Modal period and mass participation factor of the analyzed structures.

\begin{tabular}{cccccccc}
\hline Buildings & $\mathrm{T}_{\mathbf{1}}(\mathbf{s})$ & $\mathrm{T}_{\mathbf{2}}(\mathbf{s})$ & $\mathrm{T}_{\mathbf{3}}(\mathbf{s})$ & $\mathrm{U}_{\mathbf{1}}(\%)$ & $\mathrm{U}_{\mathbf{2}}(\%)$ & $\mathrm{U}_{\mathbf{3}}(\%)$ & $\mathrm{U}_{\mathbf{4}}(\%)$ \\
\hline 5STRY/RGLR & 0.929 & 0.274 & 0.000 & 79.566 & 11.778 & 0.000 & 0.000 \\
8STRY/RGLR & 1.106 & 0.340 & 0.179 & 78.823 & 10.530 & 4.515 & 0.000 \\
10STRY/RGLR & 1.325 & 0.400 & 0.205 & 76.980 & 10.727 & 4.702 & 0.000 \\
13STRY/RGLR & 1.370 & 0.432 & 0.235 & 78.120 & 10.056 & 4.083 & 0.000 \\
15STRY/RGLR & 1.581 & 0.498 & 0.271 & 77.677 & 10.043 & 4.064 & 0.000 \\
5STRY/IRRGLR & 0.781 & 0.293 & 0.140 & 75.521 & 12.881 & 7.763 & 0.000 \\
8STRY/IRRGLR & 1.056 & 0.395 & 0.198 & 73.962 & 11.490 & 6.906 & 0.000 \\
10STRY/IRRGLR & 1.252 & 0.471 & 0.226 & 71.276 & 12.558 & 6.901 & 0.000 \\
13STRY/IRRGLR & 1.271 & 0.496 & 0.257 & 73.344 & 10.866 & 6.181 & 0.000 \\
15STRY/IRRGLR & 1.506 & 0.589 & 0.298 & 72.166 & 11.672 & 5.964 & 2.564 \\
\hline
\end{tabular}

In this study, 2D models of various CMRFs were examined by using SeismoStruct (Seismosoft, 2016) computer program using nonlinear modeling techniques with different computational properties. In the calculation of the behavior of the frames under static and dynamic effects, the program can evaluate the responses of the structures by taking into account both material and geometric nonlinear behavior of the elements. Seven types of structural analysis can be performed with this software due to the technical features available in the database. These analyses can be categorized such as dynamic and static time-history analysis, conventional and adaptive pushover, incremental dynamic analysis, modal analysis and static analysis (possibly nonlinear) under quasi-permanent loading. The software allows the use of distributed inelasticity and elements with lumped plasticity, which are evaluated on formulations derived from theoretical and experimental data based on force or displacement. The numerical models described work with different assumptions during calculations, but the basic input parameters used for these elements during the use of the models are physical properties such as cross-sectional geometry and uniaxial behavior of the materials used. CFST column members and composite beams are modelled as fiber section model as shown in Figure 4.

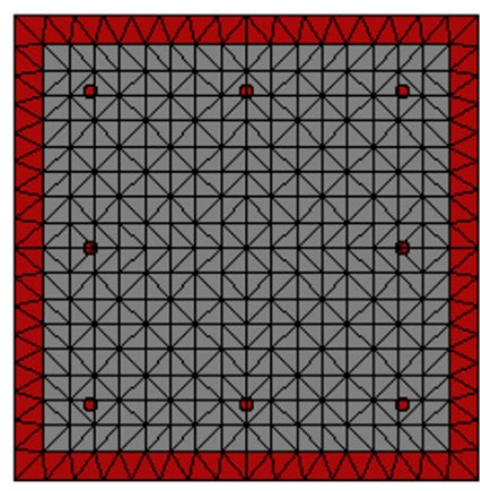

(a)

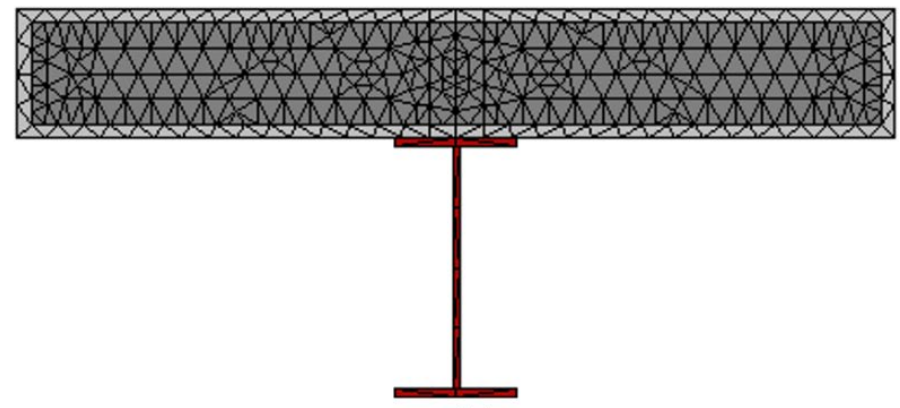

(b)

Figure 4. Fiberized section views for (a) CFST columns and (b) composite beam.

They are modelled as inelastic displacement-based frame element type and it is given as "infrmDB" in Seismosoft (2016) software. This is the displacement-based 3D beam-column element type capable of modelling members of space frames with geometric and material nonlinearities. The sectional stress-strain state is obtained through the integration of the nonlinear uniaxial material response of the individual fibers in which the section has been subdivided, fully accounting for the spread of inelasticity along the member length and across the section depth (Seismosoft, 2016). Furthermore, material models of CFST column and composite beams are selected as "con_ma" and "stl_mn" for concrete and steel, respectively. "con_ma" is developed by Martinez-Rueda and Elnashai (1997) and "stl_mn" model is developed by Monti and Nuti (1992). Both models were developed for the cycling loading condition. The concrete material constitutive model image is shown in Figure 5(a) and steel material constitutive model image of the model is given in Figure $5(b)$. It is noted that the confinement effect is higher in the concrete filled tubes than in the concrete elements which are confined with circular reinforcements (Xiao and Wu 2000; Uy 2001; Choi and Xiao 2010). In this study, the confinement effect on CFST columns is provided by steel SHS at the outermost part of the element. The confinement effect is defined by the $k_{c}$ value in the selected concrete model of the Seismosoft (2016) software. 


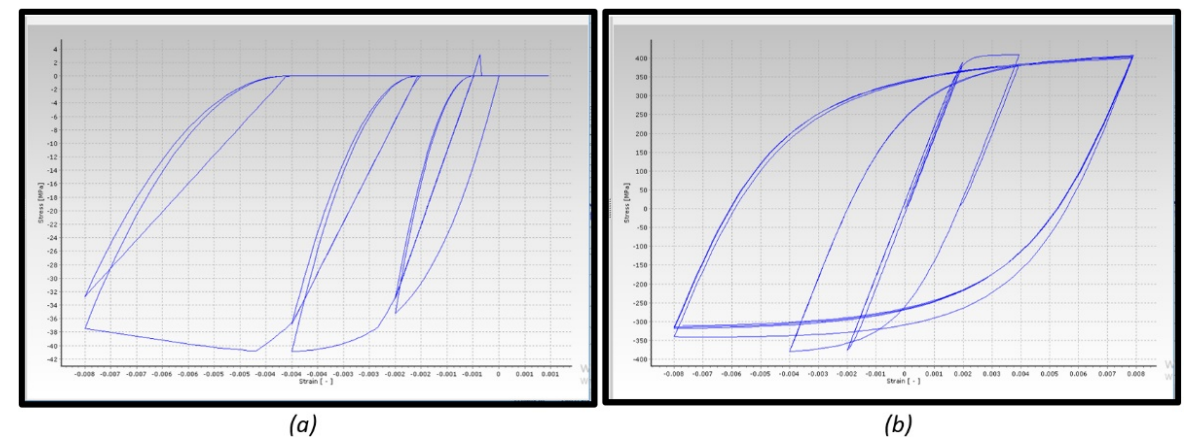

Figure 5. a) Concrete and b) steel models from SeismoStruct (Seismosoft, 2016).

The confinement factor $\mathrm{k}_{\mathrm{c}}$ is described as the ratio of the compressive strength of the confined concrete model to the plain concrete strength. Susantha et al. (2001) provided theoretical calculation methods to determine the loading capacity of CFST elements. It has been shown that the theoretical calculations give a reasonable accuracy when compared to experimental models. In this study, the modeling approach based on a large number of experimental CFST elements given in the research of Susantha et al. (2001) was used. On the other hand, in the literature, the models for the material behavior of the steel were developed by a number of researchers (Menegotto and Pinto 1973; Filippou et al. 1983; Shahrooz et al. 1993; G. Monti, C. Nuti 1996; Antoniou et al. 2008). In the modeling of the material behavior of the steel parts of the composite beams, the proposed model based on the elasto-plastic cycling loads was used. In the Seismosoft (2016) software, it is given that the element models could be created using the steel and concrete models which were sufficiently close to the experimental results in the literature when the sections were modeled with fiber elements (Xu et al. 2017). Furthermore, during the analysis, it is assumed that the shear connections between the steel and concrete in the composite beam are modeled as a complete shear connection. Therefore, the ideal behavior of the composite beam is considered as the exact interaction between the steel beam and concrete flooring would occur. Moreover, in this study, the effective floor width used for the modeling of the composite beams was taken as $1.225 \mathrm{~m}$. In the literature, Castro et al. (2007) observed that the response behavior of the structure did not changed significantly in the models obtained by using effective floor widths between Eurocode-4 (EN 1994-1-1, 2004) and Eurocode-8 (EN 1998-1, 2004). In other study forwarded by Castro et al. (2007), the effective slab widths in the composite beams were examined and the results of the tested samples were to be similar with the results suggested in such codes. In the current study, steel elasticity modulus (E), Poisson ratio $(u)$ and hardening coefficient $(\mu)$ values of the materials used in element models were taken as $210 \times 103 \mathrm{~N} / \mathrm{mm}^{2}, 0.3$ and $0.5 \%$, respectively.

In this study, panel zones of joints were modeled using modified Richard-Abbott model, which was originally developed by Della Corte et al. (2000). Seismosoft (2016) software includes this model which is capable of modeling all sorts of steel and composite connections (e.g. welded-flange bolted-web connection, extended end-plate connection, flush end-plate connection, angle connection, etc.). The model has ascending and descending parts which are defined with the moment-rotation relationship. The ascending and descending branches of the curve have been described with various parameters (i.e., initial stiffness, strength, post limit stiffness, shape factor, calibration coefficients related to pinching, damage rate, and isotropic hardening) to take into account the load reversals for the presence of both positive and negative starting points. The versatility of this type of modeling was verified previously by using the experimental data and it was noted that the model shows very good conformity (Della Corte et al. 2000; Simoes et al. 2001; Nogueiro et al. 2009; Fazaulnizam and Shamsudin 2014). In addition, some parameters were calibrated to achieve more accuracy in modeling based on the application of the component method (Jaspart and Weynand 2016).

Seismosoft (2016) software was utilized to perform the inelastic analysis. Frames were divided to small member size using by the plastic hinge length of the member along the member length. CFST columns and composite beams were divided by 5 members. Plastic hinge lengths were calculated differently for CFST column and composite beam. The divided length was applied as illustrated in Figure 6. CFST member plastic hinge length was calculated by the empirical formula with the help of the derivation of the plastic hinge length in a cantilever beams (Perea 2010). Moreover, the composite beam plastic hinge length was computed as $x_{p}=1.75 \times h_{\text {tot. }}$ In which, $h_{\text {tot }}$ is the full section height of the composite beam (Chen and Jia 2008; Pecce et al. 2012).

The evaluation of CMRF models was performed by the nonlinear static pushover (PO) analysis and incremental dynamic analysis (IDA). In PO analysis, uniform load distribution (ULD) and triangular load distribution (TLD) were considered. In IDA, several earthquake ground motions were used. The record selections were made according to the Eurocode-8 (EN 1998-1, 2004) spectra. In this study, 22 earthquake acceleration records were used to perform IDA. The characteristics of the records are given in Table 3 and these earthquake acceleration records are taken from PEER ground motion database (2014). SeismoMatch (Seismosoft, 2013) software was used to scale earthquake acceleration records. This was progressed in two stages, at the first stage, time history $(\mathrm{TH})$ records were scaled for target spectrum period ranging between 0 and $1 \mathrm{~s}$. Then, in the second stage, $\mathrm{TH}$ record series were scaled again for whole target spectrum period ranging between 0 and $4 \mathrm{~s}$. Scaling process was made with $10 \%$ tolerance in all stages. Scaled series and target spectrum are shown in Figure 7. 


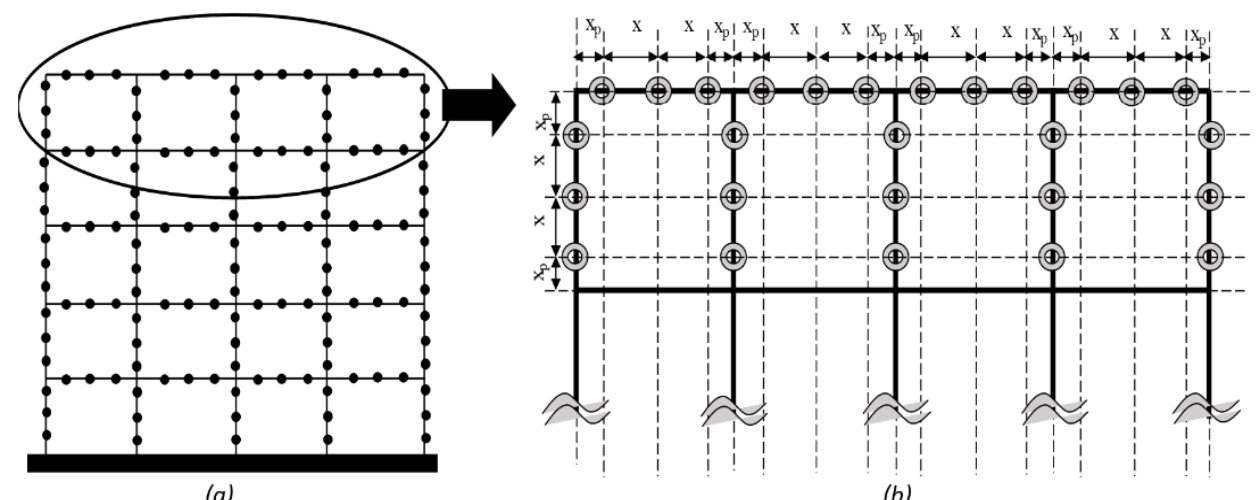

(a)

(b)

Figure 6. Composite member division schematic representation.

Table 3. Set of 22 ground motion records used (PEER 2014).

\begin{tabular}{|c|c|c|c|c|c|c|c|}
\hline Record ID & Event & Year & Station & Magnitude & Components & Mechanism & $\begin{array}{l}V s_{30} \\
(\mathrm{~m} / \mathrm{s})\end{array}$ \\
\hline TH-1 & Imperial Valley-06 & 1979 & Chihuahua & 6.53 & 140 & strike slip & 242.05 \\
\hline $\mathrm{TH}-2$ & Imperial Valley-06 & 1979 & Chihuahua & 6.53 & 230 & strike slip & 242.05 \\
\hline $\mathrm{TH}-3$ & Imperial Valley-06 & 1979 & El Centro Array \#13 & 6.53 & 45 & strike slip & 249.92 \\
\hline TH-4 & Imperial Valley-06 & 1979 & El Centro Array \#13 & 6.53 & 135 & strike slip & 249.92 \\
\hline TH-5 & Imperial Valley-06 & 1979 & Plaster City & 6.53 & 180 & strike slip & 316.64 \\
\hline TH-6 & Imperial Valley-06 & 1979 & Plaster City & 6.53 & 360 & strike slip & 316.64 \\
\hline $\mathrm{TH}-7$ & Imperial Valley-06 & 1979 & Westmorland Fire Sta & 6.53 & 0 & strike slip & 193.67 \\
\hline $\mathrm{TH}-8$ & Imperial Valley-06 & 1979 & Westmorland Fire Sta & 6.53 & 90 & strike slip & 193.67 \\
\hline TH-9 & Loma Prieta & 1989 & Agnews State Hospital & 6.93 & 12 & Reverse Oblique & 239.69 \\
\hline TH-10 & Loma Prieta & 1989 & Agnews State Hospital & 6.93 & 282 & Reverse Oblique & 239.69 \\
\hline TH-11 & Loma Prieta & 1989 & Sunnyvale - Colton Ave. & 6.93 & 270 & Reverse Oblique & 267.71 \\
\hline TH-12 & Loma Prieta & 1989 & Sunnyvale - Colton Ave. & 6.93 & 360 & Reverse Oblique & 267.71 \\
\hline $\mathrm{TH}-13$ & Hector Mine & 1999 & Hector & 7.13 & 0 & strike slip & 685.00 \\
\hline TH-14 & Hector Mine & 1999 & Hector & 7.13 & 90 & strike slip & 685.00 \\
\hline TH-15 & Chi-Chi, Taiwan & 1999 & TCU045 & 7.62 & $\mathrm{E}$ & Reverse Oblique & 704.64 \\
\hline $\mathrm{TH}-16$ & Chi-Chi, Taiwan & 1999 & TCU045 & 7.62 & W & Reverse Oblique & 704.64 \\
\hline TH-17 & Kocaeli, Turkey & 1999 & Arcelik & 7.51 & 0 & strike slip & 523.00 \\
\hline TH-18 & Kocaeli, Turkey & 1999 & Arcelik & 7.51 & 90 & strike slip & 523.00 \\
\hline TH-19 & Kobe, Japan & 1995 & Nishi-Akashi & 6.90 & 0 & strike slip & 609.00 \\
\hline $\mathrm{TH}-20$ & Kobe, Japan & 1995 & Nishi-Akashi & 6.90 & 90 & strike slip & 609.00 \\
\hline $\mathrm{TH}-21$ & Friuli, Italy-01 & 1976 & Tolmezzo & 6.50 & 0 & Reverse & 505.23 \\
\hline TH-22 & Friuli, Italy-01 & 1976 & Tolmezzo & 6.50 & 270 & Reverse & 505.23 \\
\hline
\end{tabular}

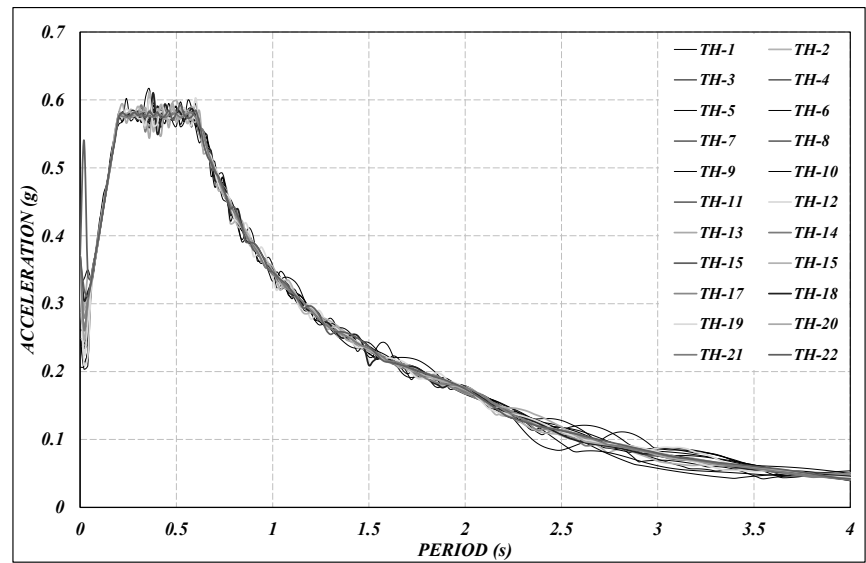

Figure 7. Scaled earthquake records against elastic spectrum. 


\subsection{Verification of fiber element model developed}

For the verification purposes, SeismoStruct model were compared with the experimental results given in the literature. In first stage, CFST columns tested experimentally under axial loadings were considered. For this, CFST specimens given in the studies of Tomii et al. (1977), Baba et al. (1995), and Schneider (1998) were modeled using fiber cross-sectional model in SeismoStruct software. During the modeling, the parameters necessary for CFSTs with box section were taking from the parametric study of Susantha et al. (2001). The tested six specimens considered in this study have b/t ratio of 27.9 to 34.9 , steel yield strength of 261.2 to $322 \mathrm{~N} / \mathrm{mm}^{2}$, and concrete strength of 18.1 to $40.5 \mathrm{~N} / \mathrm{mm}^{2}$. In Figure 8, the axial load vs. axial strain responses based on the results of SeismoStruct model and experimental results for different CFST specimens are given. It was observed that the results from the models produced with SeismoStruct were closed to the experimental test results.

In the second stage, the composite frames with steel beam to CFST columns were taken into account. To this, the experimental results given in the studies of Han et al. (2008) and Wang et al. (2009) were used and compared with the results of SeismoStruct software. A total of six composite frames were tested under cyclic lateral load with a fixed axial loading condition. One bay one story frames were constructed considering column height of $1.45 \mathrm{~m}$ and steel beam span of $2.5 \mathrm{~m}$. For the test frames, the axial load level $(\mathrm{n})$ varied from 0.04 to 0.6. Figure 9 shows the comparison of the experimental results and those obtained from the SeismoStruct models. It was pointed out that the ultimate lateral load capacity of the numerical results of SeismoStruct model varied between $83 \%$ and $95 \%$ to that of the experiments (Han et al. 2008; Wang et al. 2009).
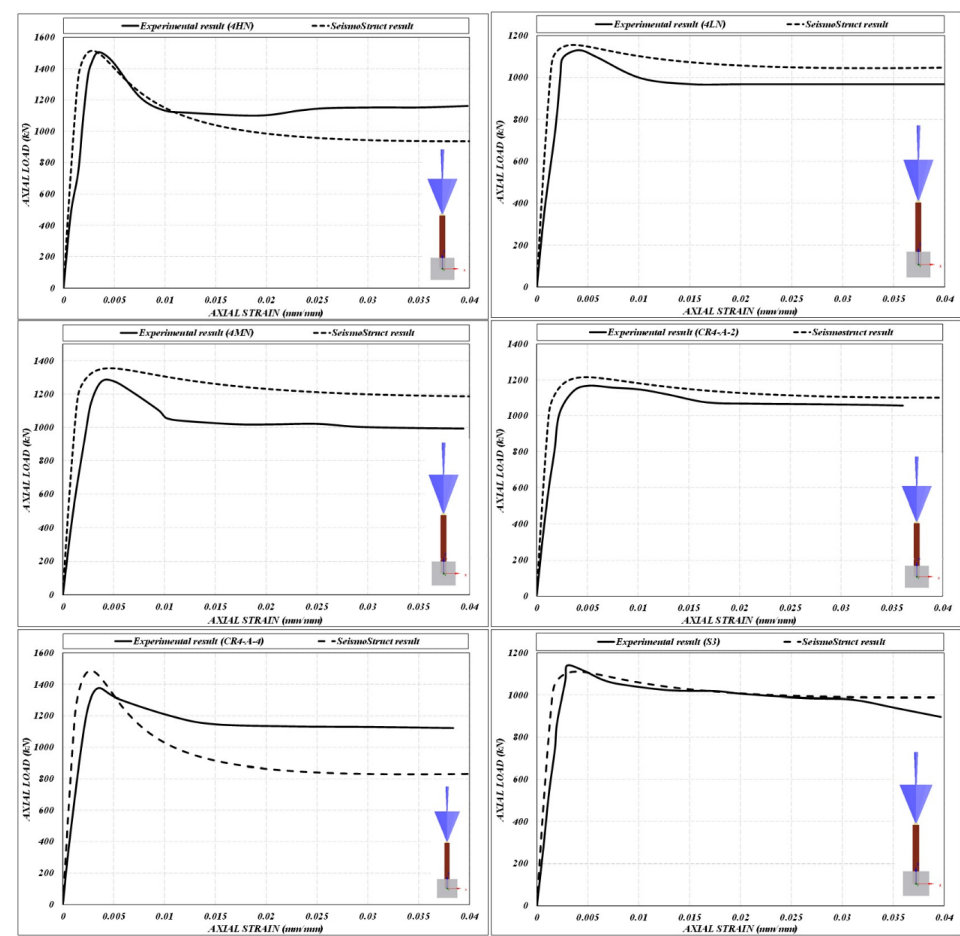

Figure 8 Verification of SeismoStruct model against the experimental results for CFST columns having box section (Tomii et al. 1977; Baba et al. 1995; Schneider 1998; Susantha et al. 2001)
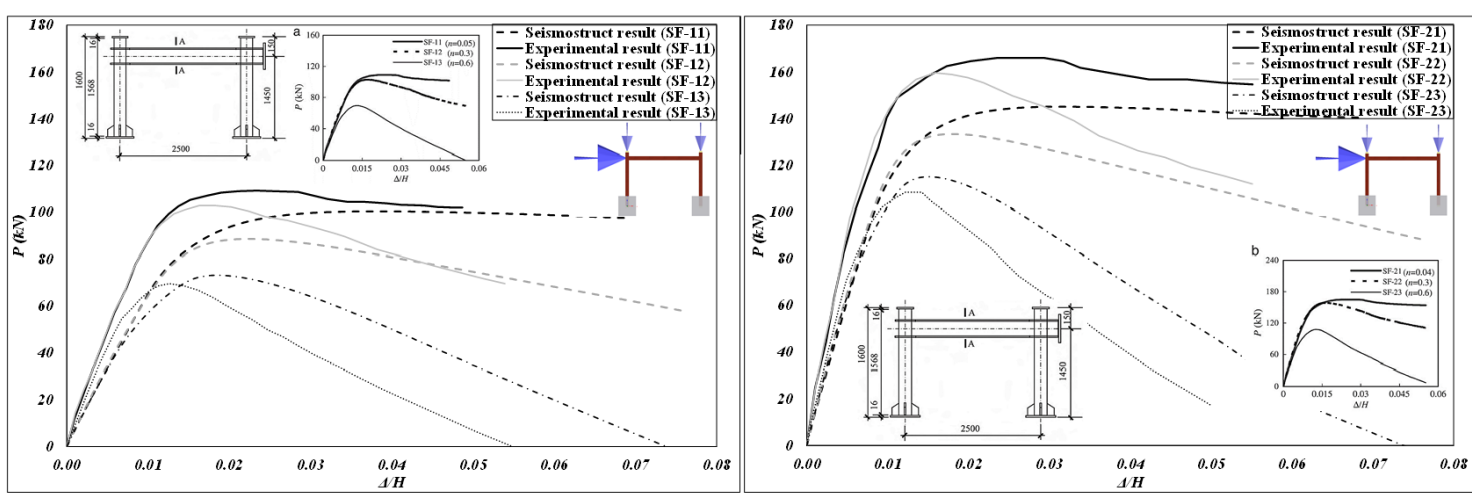

Figure 9 Verification of SeismoStruct model against the experimental results for CFST frames (Han et al. 2008; Wang et al. 2009). 


\section{RESULTS AND DISCUSSION}

\subsection{Lateral response of the structures}

The response of regular and irregular CMRFs as a result of PO analysis with ULD and TLD is shown in Figure 10. The horizontal axis indicates the ratio of the roof displacement to the building height while the vertical axis shows the ratio of the base shear to the structure weight. In the regular frames, PO analysis performed with TLD indicates closely a first mode-dominated response. Moreover, PO analysis conducted with ULD give better results if higher modes contribute notably to the response or when substantial inelastic concentrations occur (Vamvatsikos and Cornell 2005; Castro et al. 2008). The IDA was performed by using selected TH records to obtain the seismic response of the case study CMRFs. The dynamic behavior of the structures is also plotted in Figure 10.
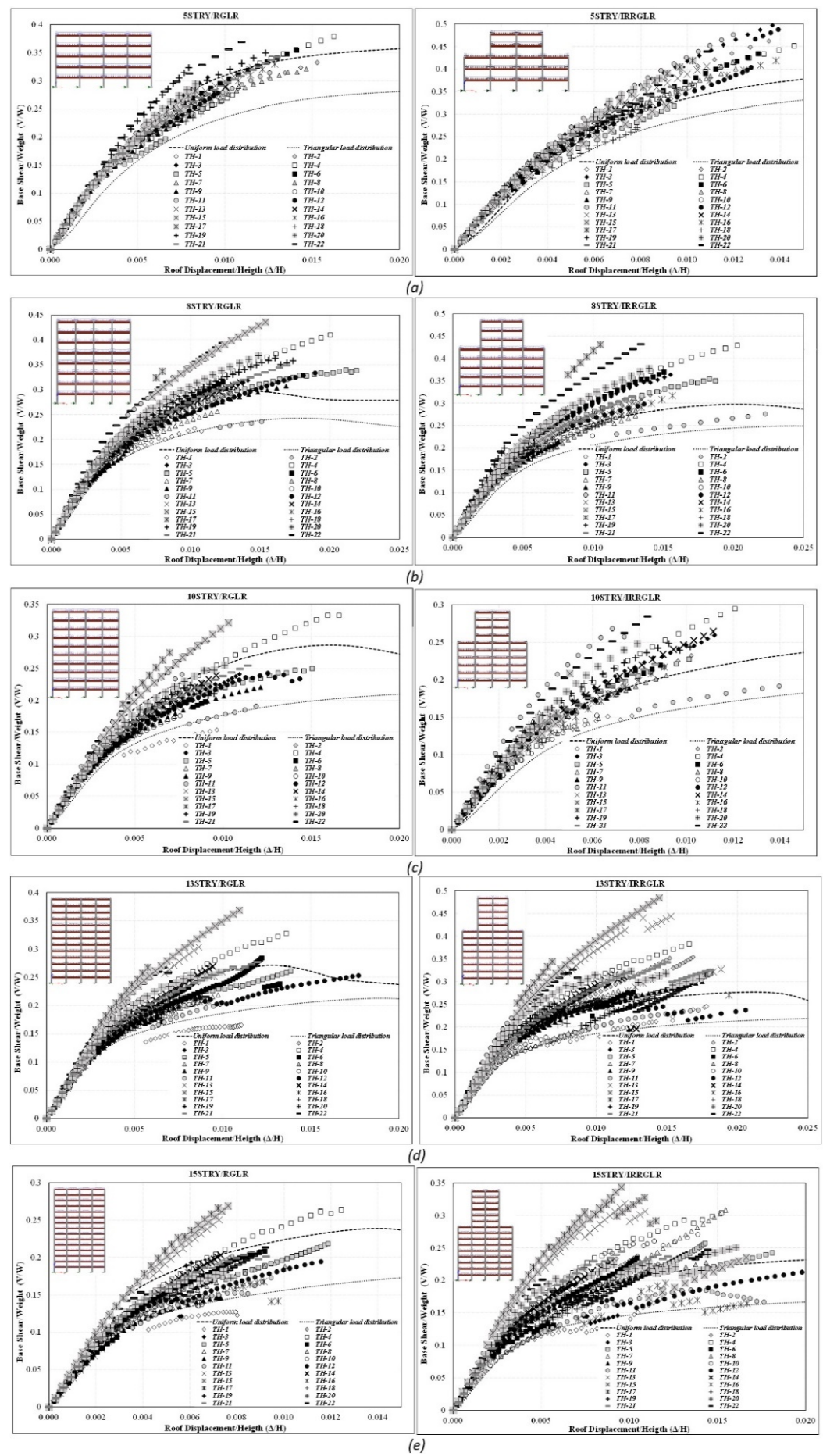

Figure 10. PO analysis and IDA graphs for regular and irregular structures a) 5, b) 8, c) 10, d) 13, and e) 15 stories. 
PO analysis and IDA were compared to understand the general validity of the results. It was pointed out that the results of former showed a relatively good correlation with those of the latter. Especially, on an average, the distribution of the data based on IDA was very closely to that of PO analysis performed with ULD as shown in Figure 10. Furthermore, it was noted that the uniform distribution provides an envelope of the global behavior rather than a realistic representation of the mean level of dynamic response (Castro et al. 2008).

\subsection{Global yielding}

To determine the seismic performance of CMRFs, some key parameters are obtained from the nonlinear static and dynamic analysis. These parameters are limit states that are defined by the access to the collapse and global yielding state of the structure. Different definitions are given for the evaluation of the global yielding point obtained from the base shear-roof deformation curve. Stiffness defines the relationship between the movements and deformations of a structure and its components. Member stiffness is a function of cross-sectional properties, length, and boundary conditions, and system stiffness is a function of lateral resistance mechanisms used such as moment-resistant frames (MRFs), supported frames, walls or dual systems. The relationships between geometry, mechanical properties, actions, and deformations can be derived from the principles of mechanics. Their complexity depends on the construction material used. Cracking of concrete, section of steel tube, physical and mechanical properties, connection properties and other inflexible welds in CMRF structures cause problems in defining a constant stiffness value. For CMRFs and MRFs structures, the stiffness can be taken as the secant to the yield point or any other point selected in the response curve. Some methods used to describe this point have been applied as follows as deformation corresponding to; (a) the first yielding, (b) the yield point of an equivalent elasto-plastic system with the same elastic stiffness and ultimate load as the real system, (c) to the yield point of an equivalent elasto-plastic system with the same energy absorption as the real system, and (d) the yield point of an equivalent elasto-plastic system with reduced stiffness computed as the secant stiffness at $75 \%$ of the ultimate lateral load of the real system (Park 1988; Whittaker et al. 1999; Thermou et al. 2004).

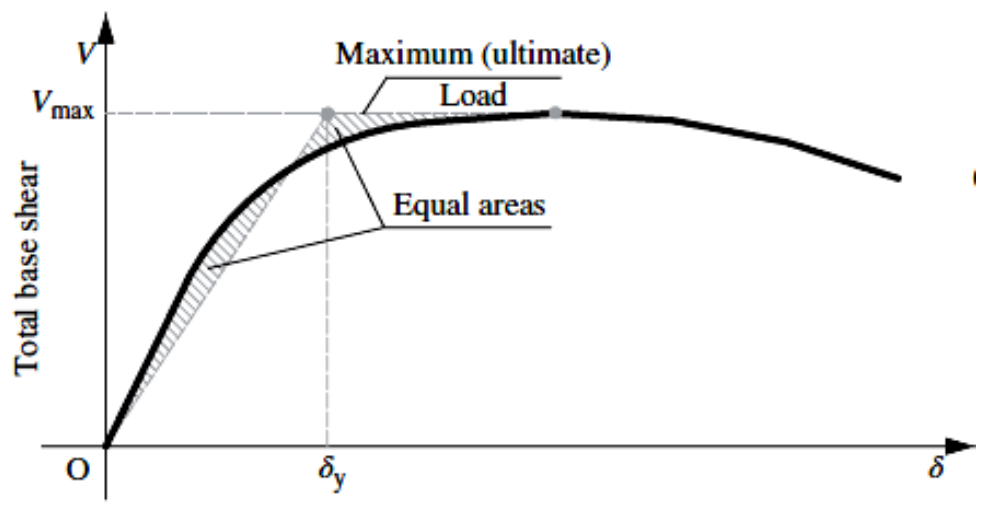

Top lateral displacement

Figure 11. Yielding point representation (Elnashai and Luigi 2015).

In this study, the stiffness was evaluated through the global yield point determination considering the elasto-plastic energy absorption method as shown in Figure 11. In most of the previous studies, this method was proposed in the determination of the global yielding point and it was utilized to compute the seismic performance parameters for MRF type structures (Tomii et al. 1977; Park 1988; Mwafy and Elnashai 2001; Elghazouli et al. 2008; Pecce et al. 2012; Ferraioli et al. 2014; Elnashai and Luigi 2015; Yahmi et al. 2017). The inertial force due to earthquakes in which a global yielding begins in a CMRF structure, (1) the load factor applied to the code-specified design seismic force; (2) the structural weights in the building during the seismic event are much lower than the factor weight loads used in the design; (3) the power reduction factors used in design specifications; (4) higher real power of materials than specified force; (5) larger element sizes than those required for durability considerations; and (6) special ductility requirements (Jain and Navin 2002). As seen in Figure 12, for the IDA results, in the regular and irregular CMRFs examined within the scope of the study, the secant stiffness points were determined as approximately $70-75 \%$ of the ultimate load capacity. In addition, these values were estimated to be about 80 to $85 \%$ for PO analysis with ULD and TLD. In theoretical studies conducted in the literature, this value was observed as $75 \%$ for the reinforced concrete and steel-concrete composite structures (Park 1988; Mwafy 2001; Thermou et al. 2004). 


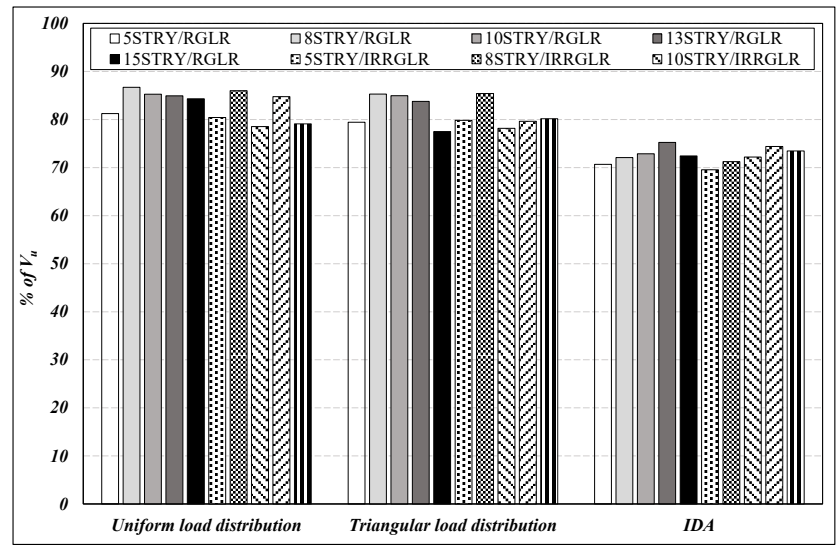

Figure 12. Yielding points results.

\subsection{Interstory drift response}

To observe the drift demand of the designed regular and irregular structures, the dynamic analysis was performed. For this, interstory drift response of these structures were evaluated considering the design basis earthquake (DBE) with $10 \%$ probabilities of exceedance in 50 years and maximum considered earthquake (MCE) with $2 \%$ probabilities of exceedance in 50 years which are defined in ASCE/SEI 7-10 (2013). The analysis of the results on the variation of the inter-story drift ratio (IDR) for the regular and irregular frame models under 22 ground accelerations in two groups as DBE and MCE are given in Figure 13. It was obtained that the average IDR results based on DBE for 5-, 8-, 10-, 13- and 15story regular CMRFs were $0.00561,0.00518,0.00497,0.00440$ and 0.00426 , respectively. On the other hand, for the irregular CMRFs, those corresponded to $0.00483,0.00480,0.00456,0.00413$ and 0.00400 , respectively. Moreover, in the case of MCE, the average IDR results were obtained as $0.01014,0.0094,0.00925,0.00822$ and 0.00777 for 5-, 8-, 10-, 13and 15-story regular CMRFs, respectively while those for the irregular CMRFs were evaluated as 0.0092, 0.0086, 0.00855, 0.00761 and 0.00748 , respectively. In Eurocode-8 (2004), the IDR limit is calculated as $1.5 \%$ considering $\psi$ value as $0.75 \%$, $v=0.5$ for a building of an importance class II. Thus, the inter-story drift responses mentioned above were observed to be less than the corresponding value.
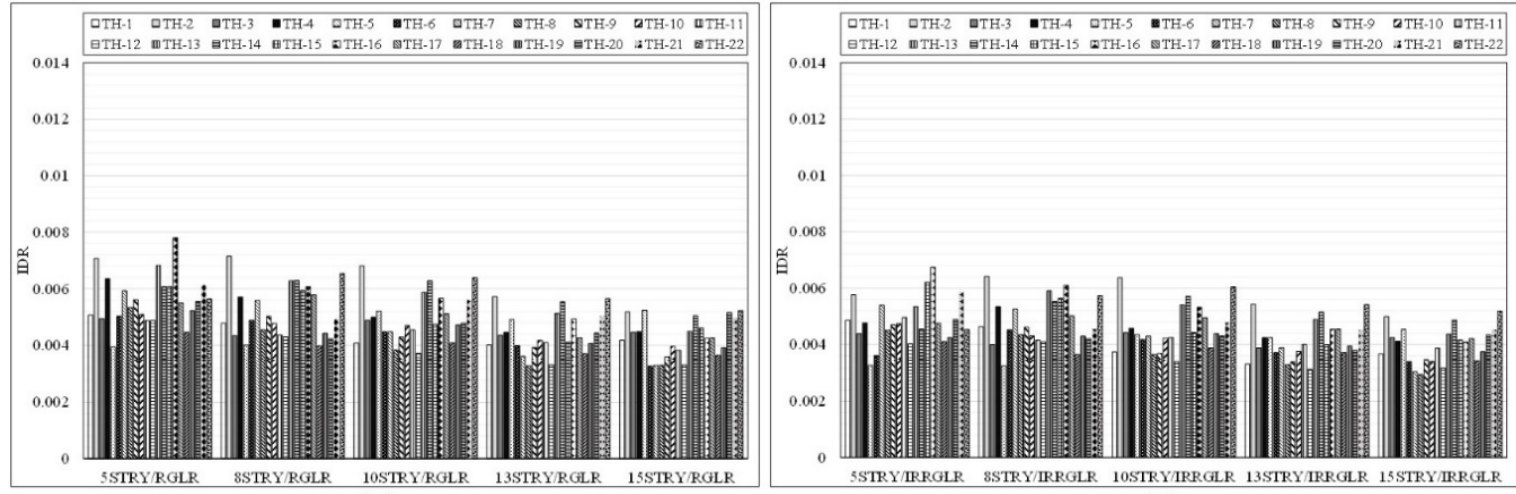

(a)

(b)
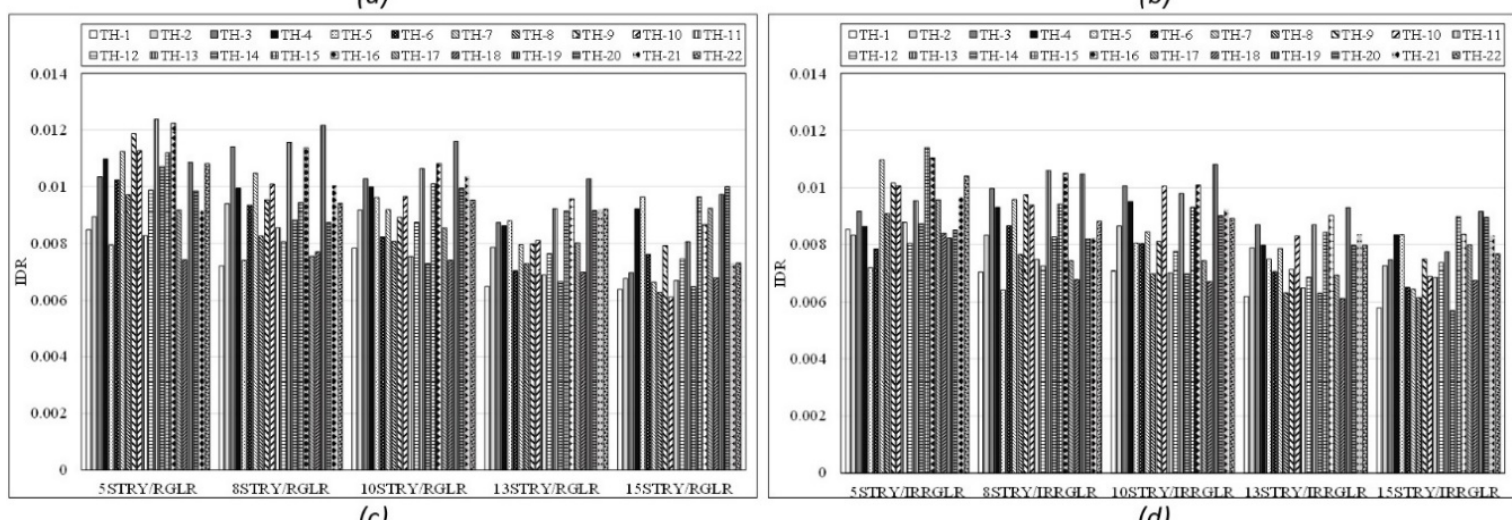

(d)

Figure 13. Maximum IDR values for a) regular and b) irregular structures under DBE while for a) regular and b) irregular structures under MCE. 


\subsection{Ductility factor}

In the widespread application of the earthquake-resistant design, the term ductility is used to assess the performance of structures by showing the amount of seismic energy that can be dispersed through the plastic deformations. The use of the ductility concept allows the reduction of seismic design forces and permits to produce some controlled damage within the building in the case of strong earthquakes. The ductility capacity is a key factor in the seismic design of the buildings by considering the plastic properties. The flexibility of a structure allows us to estimate the final capacity of the structure. This is an important criterion for the design of structures under conventional loads (Victor and Federico 2002).

According to the study by Miranda and Bertero (1994), the ductility rate is used to express the degree of inelastic deformation that occurs when a structural system is subjected to a specific earthquake ground motion or a horizontal load. The displacement ductility rate $\mu$ (ductility demand) is given below. This ratio indicates the maximum absolute relative displacement demand of the structure.

$\mu=\frac{\Delta_{\mathrm{u}}}{\Delta_{\mathrm{y}}}$

Yield and ultimate displacement values are $\Delta_{\mathrm{y}}$ and $\Delta_{\mathrm{u}}$, respectively, in Eqn (1). Another definition for ductility is defined as the ability of a material, component, connection, or structure to undergo inelastic deformations with acceptable stiffness and strength reduction. Structures are often designed to respond inelastically under the influence of severe earthquakes because this is the principle of economic design (Elnashai and Luigi 2015). The severity of the reactions of the structures affected by the earthquake depends on the energy damping capacity of the structure, which is related to the energy damping and distribution capacity within the ductile behavior of the structures (Zahrah 1984).

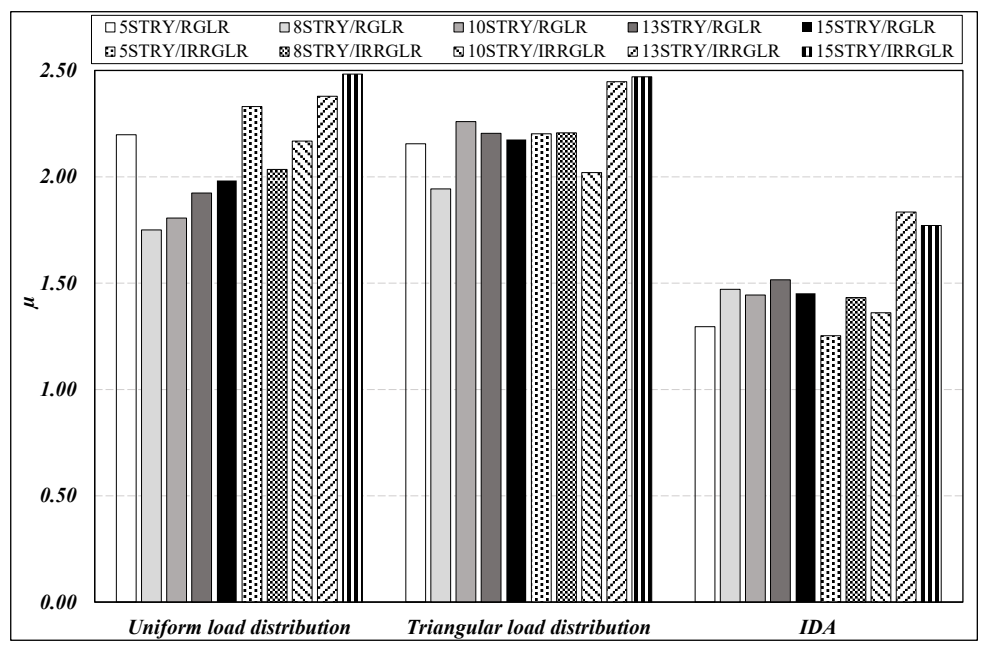

Figure 14. Ductility factor results.

In this work, CMRFs were designed as DCH systems and the obtained $\mu$ results are given in Figure 14 . The reduction factor attributed to ductility $\left(R_{\mu}\right)$ was used to measure the nonlinear response of a structure originating from the hysteretic energy. $R_{\mu}$ depends on structural features such as ductility, damping and basic vibration period as well as the characteristics of earthquake ground motion. The parameter $R_{\mu}$ can be expressed in terms of the maximum structural drift and the deviation corresponding to the idealized yield point developed by Newmark and Hall (1982).

Newmark and Hall (1982) also showed that the structural vibration period can be used as $R_{\mu}=\mu$ if it is greater than $0.5 \mathrm{~s}$. In this study, it was pointed out that PO analysis showed greater $\mu$ value against IDA. Moreover, when the natural vibration periods of the designed CMRFs were examined, it was observed that these values were higher than $0.5 \mathrm{~s}$. As a result, it was noted that the ductility capacities obtained could be taken equal to $R_{\mu}$ value. This value achieved from IDA was recorded as 1.44 and 1.53 for the regular and irregular CMRFs structures, respectively (Figure 14).

\subsection{Overstrength factor}

For the nonlinear response of the structures, the load-displacement relationship is generally estimated to be elastoplastic; this can be done in various ways. The idealization adopted in this study is shown in Figure 11. Structural overstrength factor expressed as the following equation; 
$\Omega_{\mathrm{d}}=\frac{V_{\mathrm{y}}}{V_{\mathrm{d}}}$

Yield and design base shear values are displayed as $V_{y}$ and $V_{d}$, respectively, in Eqn (2). Another determination of overstrength $\left(\Omega_{\mathrm{d}}\right)$ is "observed overstrength" factor. As a result of the experimental and theoretical studies conducted by the researchers to determine the performance of the building, the overstrength factor in the face of severe earthquakes has played an important role in protecting the buildings from collapse (Whittaker et al. 1999; Elnashai and Mwafy 2002; Elnashai and Luigi 2015). Capacity design procedures used in more ductile structures can cause significant members and structural overstrength. The design and elaboration of provisions requiring minimum quantities and maximum reinforcement intervals can make an important contribution to over-strengthening. Confinement requirements increase the strength and deformability of the reinforced concrete elements. It has been proved experimentally and theoretically that the effect of confinement on the columns having CFST sections has better values than the performance of the reinforced concrete elements. It is believed that the use of such elements would constitute a vital factor in the overstrength factor calculations of the structure. Both material overstrength and strain hardening of steel material contribute to the overstrength of the structure (Susantha et al. 2001; Jain and Navin 2002; Mitchell and Paultre 2010).

Flexural overstrength may be caused to collapse mechanism based on failure in column or brittle shear failure at beams in MRFs. Shear failure of columns or soft story failure mode can be observed due to the non-structural elements. In addition, the period of the structure, the design intensity level, load cases other than seismic action, the structural system, the ductility level employed in the design and other parameters mentioned above are the effective key parameters influencing the $\Omega_{d}$ factors (Park 1996; Elnashai and Luigi 2015). In the literature, overstrength values were reported in the range of 1.8 to 6.5 for the structures with long and short period (Elnashai and Luigi 2015). In this study, IDA showed that the ultimate load was reached by the shear failure of beams because of the high overstrength factor of CMRFs. For IDA results, the values of $\Omega_{d}$ for the regular buildings were greater than 5.2 while those for the irregular ones were higher than 4.5 as shown in Figure 15. Regular frame systems had greater overstrength factors against the irregular ones (Figure 15). Similarly, in the case of PO analysis with both UDL and TDL, $\Omega_{d}$ factors for the regular structures were greater than those for irregular structures. Among the three types of analysis, PO analysis with both TDL yielded lower factors.

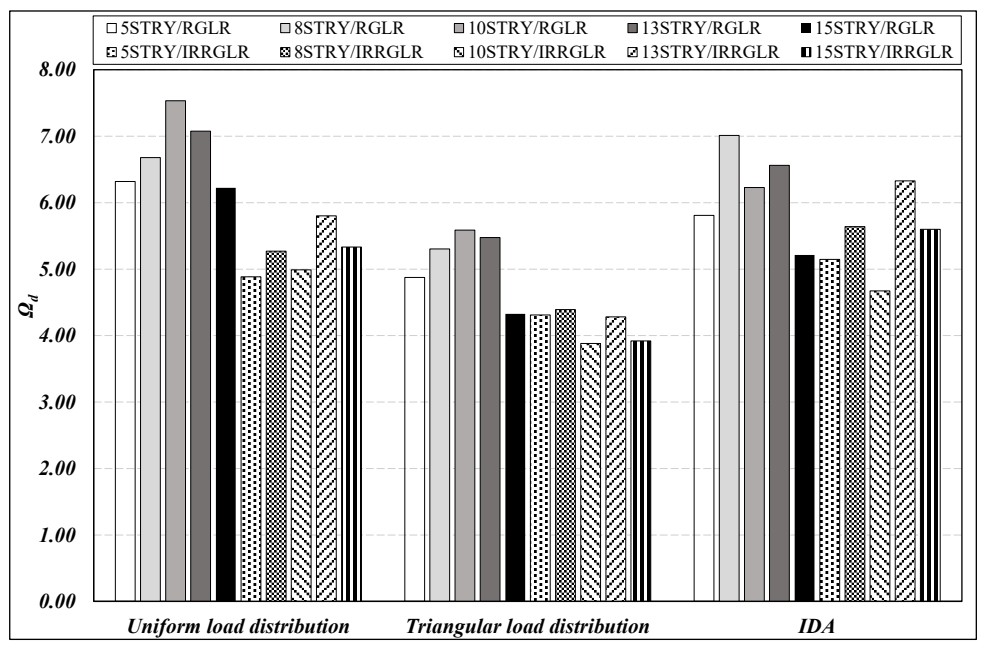

Figure 15. Overstrength factor results.

\subsection{Inherent overstrength factor}

Elnashai and Mwafy (2002) recently suggested a measure of response termed 'inherent overstrength factor. Inherent overstrength factor $\left(\Omega_{\mathrm{i}}\right)$ is formulated as below;

$\Omega_{\mathrm{i}}=\frac{V_{\mathrm{y}}}{V_{\mathrm{e}}}$

Yield and elastic base shear values are given as $V_{y}$ and $V_{e}$, respectively, in Eqn (3). 


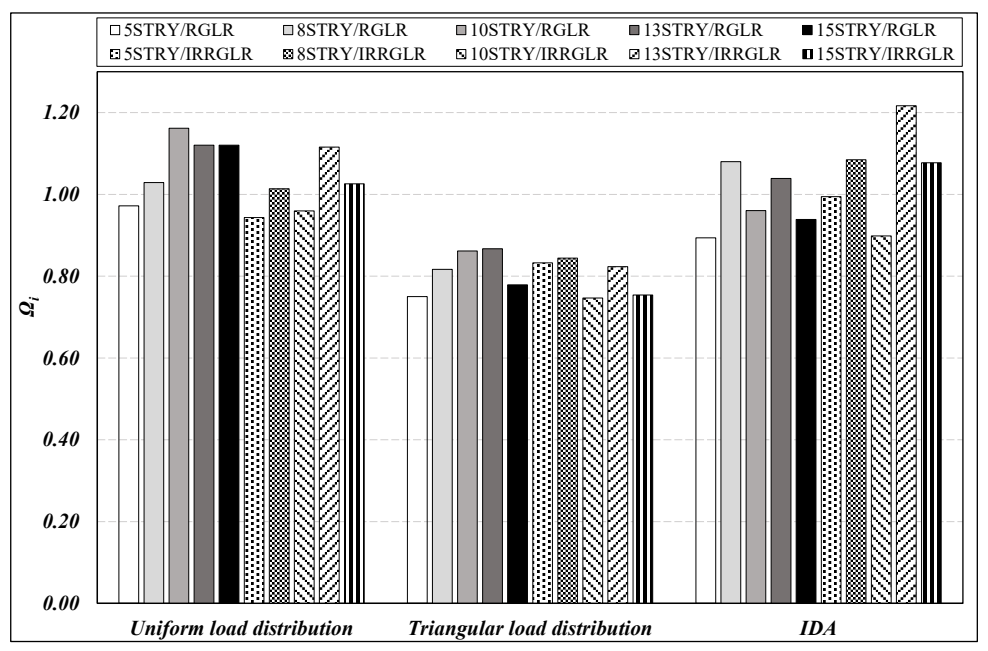

Figure 16. Inherent overstrength factor results.

The suggested measure of response $\Omega_{\mathrm{i}}$ reflects the reserve strength and the anticipated behavior of the structure under the design earthquake. Clearly, in the case of $\Omega_{i} \geq 1.0$, the global response will be almost elastic under the design earthquake, reflecting the high overstrength of the structure. If $\Omega_{\mathrm{i}}<1.0$, the difference between the value of $\Omega_{\mathrm{i}}$ and unity is an indication of the ratio of the forces that are imposed on the structure in the post-elastic range (Elnashai and Luigi 2015). According to the PO analysis results for CMRFs, the $\Omega_{i}$ values obtained for ULD were mostly greater than 1.0 and all $\Omega_{i}$ values obtained for TLD were less than 1.0 (Figure 16). Moreover, $\Omega_{i}$ values for IDA results did not show a clear trend but they were commonly higher than 1 for the irregular structures.

\subsection{Response modification factor}

Seismic codes forecast a decrease in design loads because of their high reserve force (overstrength) and energy dissipation capacity (ductility). For this, a force reduction or reaction reduction factor during structural design under earthquake effects is considered. This factor represents the ratio of the seismic force in the structure to the maximum force during the specified ground motion, if the behavior of the structure remains under elastic limits under the influence of the force under the seismic conditions in which the design is made. Thus, the actual seismic forces are reduced by the factor R to obtain the design forces. The basic flaw in the code procedures is that they use linear methods but rely on the nonlinear behavior (Kim and Choi 2005; Asgarian and Shokrgozar 2009).

Eurocode 8 (2004) uses the behavior factor $(q)$ to reduce the elastic response spectrum while the response modification factor (R) is utilized in FEMA P-695 (2009) and UBC (1997). Moreover, SEAOC (1999) considers the R factor as a system quality factor or a system performance factor. In this study, both terms "behavior factor" and "response reduction factor" given in the codes were considered. These factors were obtained from the static and dynamic analyses and compared with each other.

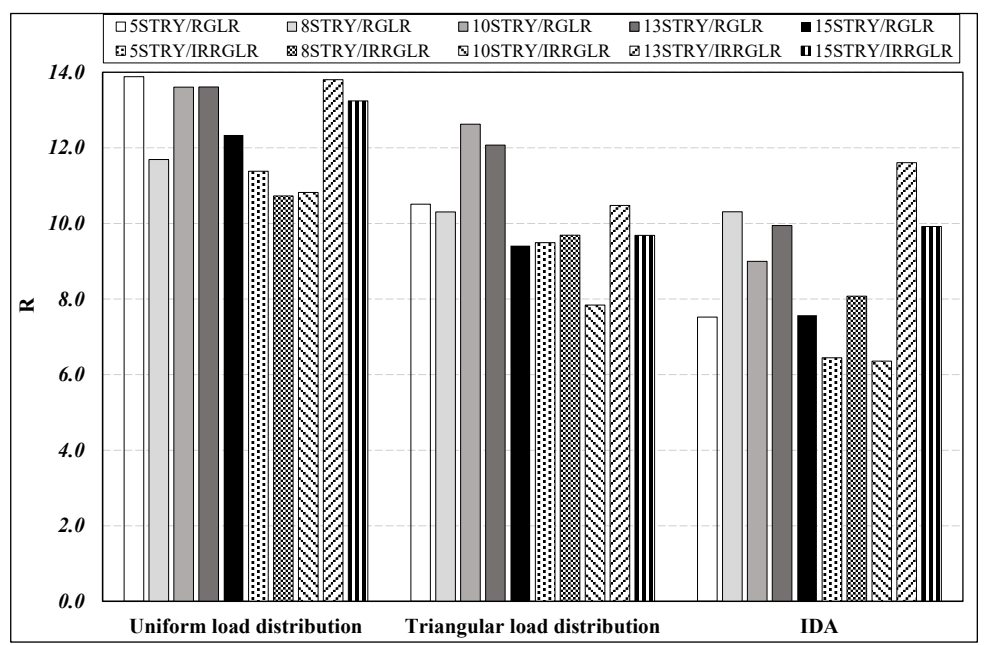

Figure 17. Response modification factor results. 
Force reduction factors are required to design the earthquake-resistant structures. The response modification factors proposed for the first time in ATC (1978) are selected according to the observed performance of the buildings during the previous earthquakes and excessive force and damping estimates (ATC 1995). The response modification factors were calculated according to ATC (1978) and ATC (1995). Such factors are the rate of force required to provide structural flexibility in seismic design procedures based on force. They are important for estimating the seismic strength of a building. Response modification factor $(R)$ is based on the ductility $(\mu)$, overstrength $\left(\Omega_{d}\right)$, and redundancy $(\rho)$. In this study, the load-displacement curve was used to evaluate these factors. Considering the effects of overstrength ( $\left.R_{S}\right)$, ductility $\left(R_{\mu}\right)$, and redundancy $\left(R_{R}\right)$, $R$ can be expressed as follows:

$R=\mathrm{R}_{S} \times \mathrm{R}_{\mu} \times \mathrm{R}_{\mathrm{R}}$

Figure 17 shows the variation of $\mathrm{R}$ factor values for the regular and irregular CMRFs. From the PO analysis, a minimum value of 9.4 and a maximum value of 13.9 were identified for the regular CMRFs while those values for irregular ones were obtained as 7.8 and 13.8 , respectively. From IDAs, the minimum and maximum values were 7.5 and 10.3 for the regular structures and 6.4 and 11.6 for the irregular ones. Moreover, on an average, the values obtained from the PO analysis with ULD and TLD for the regular CMRFs were obtained as 2.00 and 1.69 times of the behavior factor used in the design, respectively. On the other hand, when the behavior factor was calculated from the PO analysis with ULD and TLD for the irregular CMRFs, the average of the factors was found as 2.31 and 1.82 times of the behavior factor given in the design, respectively. In addition, these values obtained as a result of IDAs for the regular and irregular CMRFs were as large as 1.37 and 1.63 times, respectively. These findings were agreed with those given in the study of Elnashai and Broderick (1996). They observed that the analytically identified behavior factors for the frames under different ground motions were well above those given in the codes and it was noted that the present design standards on the behavior factors for the composite frames seemed to be too conservative.

It is noted that Eurocode-8 (2004) uses a sensitivity coefficient for the consideration of P-Delta effects in the seismic design of structures. Thus, the seismic design procedure of MRFs in Eurocode-8 (2004) is severely affected by P-Delta effects and damage limitations (i.e. drift control) which cause increasing in the structural lateral stiffness and resistance. Indeed, as reported in the studies of Tenchini et al. (2014), Cassiano et al. (2016), and Tartaglia et al. (2018), these aspects are responsible of quite large overdesign. Similarly in the current study, for both the regular and irregular structures, the calculated R or q factors were observed to be greater than the design stage values.

\subsection{Dynamic behavior factor}

In the literature, several calculation methods for the behavior factors, which clearly represent the behavior of the structure under the dynamic analysis, have defined (Broderick and Elnashai 1996; Ferraioli et al. 2014; Louzai and Abed 2015; Yahmi et al. 2017). The dynamic behavior factors of the structures can also be evaluated as given in Eqn (5) (Thermou et al. 2004);

$q_{\mathrm{c}, \mathrm{dy}}=\left(S_{a}\right)_{c}^{e l} /\left(S_{a}\right)_{d}^{i n}$

where $\left(\mathrm{S}_{a}\right)_{c}{ }^{\text {el }}$ and $\left(\mathrm{S}_{\mathrm{a}}\right)_{d}{ }^{\text {in }}$ parameters are explained as elastic design spectral acceleration and inelastic design spectral acceleration, respectively.

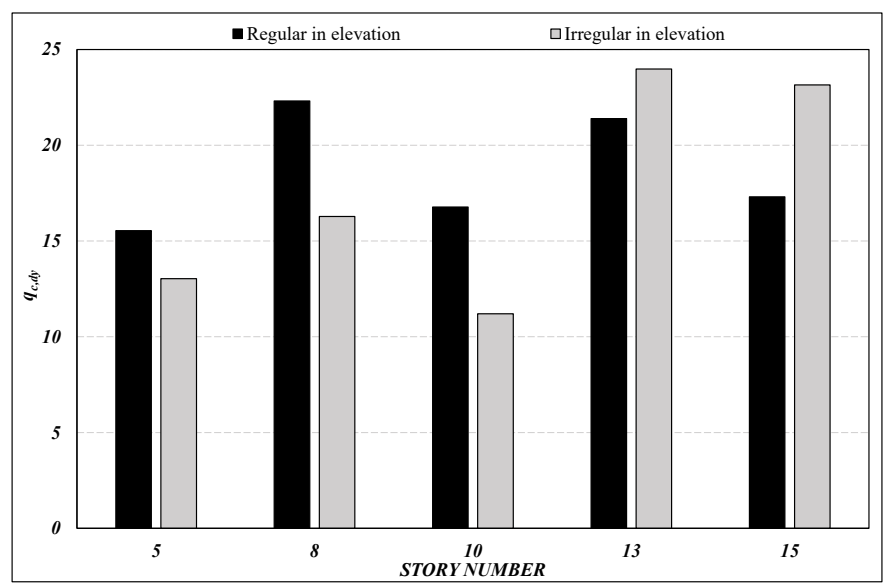

Figure 18. $\mathrm{q}_{\mathrm{c}, \mathrm{dy}}$ results. 
Moreover, the dynamic behavior factor was symbolized with the subscripts " $c$ " and "dy" given in the above equation indicate the collapse and design yield strength, respectively (Thermou et al. 2004). The $q_{c, d y}$ values obtained from the IDA results of the structures are presented in Figure 18.

When these values were examined, it was pointed out that the values used in the designs were greater than the behavior factors given in Eurocode 8. It was also observed that the mean $q_{\mathrm{c} \text {,dy }}$ values were 18.7 and 17.5 for the regular and irregular structures, respectively. As seen from the figure, the 5, 8 and 10-story regular CMRF structures had greater $q_{\mathrm{c}, \mathrm{dy}}$ values compared to those for the irregular ones. However, for 13 and 15-story irregular CMRF structures, these $q_{\mathrm{c}, \mathrm{dy}}$ values were higher than regular ones. It is noted that when the values of the global yielding state of the structure are used, Eqn (5) can be rewritten as given below (Thermou et al. 2004);

$q_{\mathrm{c}, \mathrm{ay}}=\left(S_{a}\right)_{c}^{e l} /\left(S_{a}\right)_{y}^{e l}$

where $\left(S_{a}\right)_{y}{ }^{\text {el }}$ is defined as design yield spectral acceleration. When the dynamic behavior factor reorganized, it was symbolized with the subscripts "ay" as given in the above equation. This indicates the actual yield strength (Thermou et al. 2004). The $q_{c \text {, ay }}$ values obtained from the IDA results of the structures are given in Figure 19. The analysis of the results indicated that the regular structures had an increasing trend for $q_{\mathrm{c} \text {,ay. However, the irregular structures }}$ showed some fluctuating trend with increasing number of stories. Furthermore, $q_{c, a y}$ results showed that all CMRFs studied exhibit well above the design values.

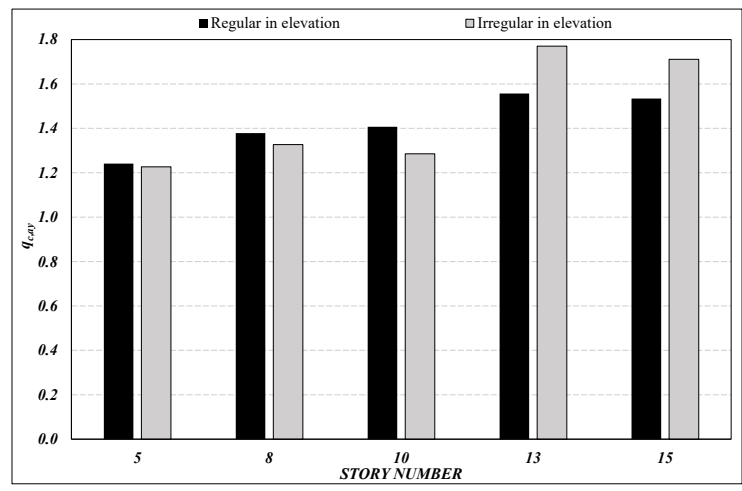

Figure 19. $\mathrm{q}_{\mathrm{c}, \mathrm{ay}}$ results.

To obtain more realistic values for the definition of $q_{c, \text { ay }}$, it is suggested to include terms indicating the ductility behavior of the structure. This factor is predicted as $\Omega_{d}$ indicating the ductility value of the structure (Elnashai and Broderick 1996; Thermou et al. 2004; Elghazouli et al. 2008). Rewriting the Eqn (6) with this defined expression provides;

$q_{\mathrm{c}, \mathrm{ay}}^{\prime}=\Omega_{d} \times q_{\mathrm{c}, \mathrm{ay}}$

As seen from Figure 20, $q_{\text {c,ay }}^{\prime}$ values for the regular CFSTs gave the highest result as 10.2 and the lowest one as 7.2 . Thus, it was observed that the regular CMRFs had the dynamic behavior factors that were about 10 to $57 \%$ greater than the design behavior factor. Moreover, for irregular cases, the $q_{c \text {,ay }}^{\prime}$ values reached the maximum result as 11.2 and the minimum one as 6.0. Thus, the dynamic behavior factors for the irregular structures showed greater differences from the design value in comparison to the regular ones.

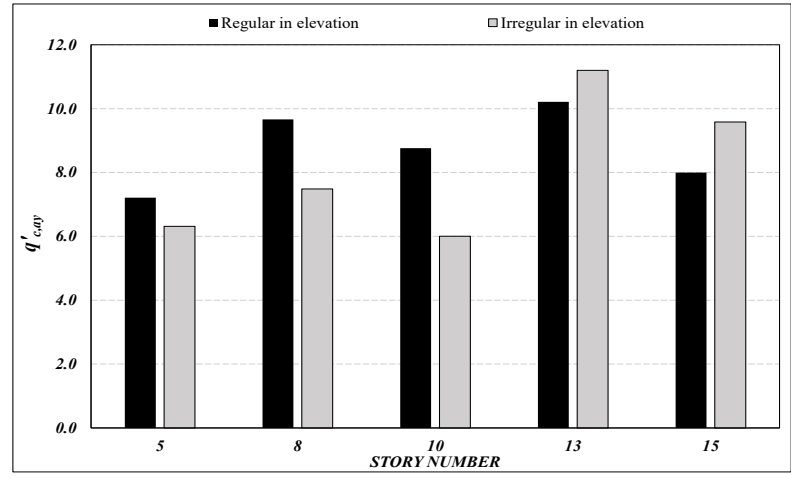

Figure 20. $\mathrm{q}_{c, \text { ay }}^{\prime}$ results. 


\section{CONCLUSIONS}

Performance assessment of regular and irregular composite moment resisting frames (CMRFs) was investigated in this study by utilizing various parameters. For this, pushover analysis with two different lateral load patterns and incremental dynamic analysis were performed. It was observed that the structures reached the global yielding position under the effects of the design earthquake and they started to lose their elastic behavior. In all CMRF structures examined within the scope of the study, the global yielding of the structure was recorded to be between $80-85 \%$ of the ultimate load capacity in the pushover analysis while that corresponded to be between $70-75 \%$ in the incremental dynamic analysis. Moreover, the load-displacement responses of the case study structures indicated that they behaved in a ductile manner under the given earthquakes. The analysis of the results indicated that the lowest response modification factors based on the pushover analysis with uniform and triangular load distributions for the regular CMRFs were gathered as 1.80 and 1.44 times of the behavior factor used in the design, respectively. Moreover, in the case of the irregular CMRFs, it was observed as 2.06 and 1.52 times, respectively. These values obtained from incremental dynamic analysis for the regular and irregular structures were as high as 1.15 and 1.23 times, respectively. Similarly, when the dynamic behavior factors of regular and irregular cases were evaluated, they were observed to be above the values considered in the design, respectively.

Author's Contributions: Methodology, investigation, S Etli, EM Güneyisi; Analysis, S Etli; Writing, review and editing S Etli, EM Güneyisi.

Editor: Pablo Andrés Muñoz Rojas.

\section{References}

Antoniou, S., Fragiadakis, M., Pinho, R., (2008). Modelling inelastic buckling of reinforcing bars under earthquake loading, pp. 347-361.

ASCE/SEI 7-10, (2013). Minimum Design Loads for Buildings and Other Structures. ANSI/ASCE Standard. American Society of Civil Engineers, Reston, VA.

Asgarian, B., Shokrgozar, H.R., (2009). BRBF response modification factor. Journal of Constructional Steel Research 65:290298.

ATC, (1978). Tentative Provisions for the Development of Seismic Regulations for Buildings Rep. No. ATC-3- 06, Redwood City, Calif. Rep No. ATC-3-06.

ATC, (1995). A Critical Review of Current Approaches to Earthquake-Resistant Design Rep. No. ATC-34, Redwood City, Calif. Rep No ATC-34.

Baba, T., Inai, E., Kai, M., T, N., Mukai, A., (1995). Structural behaviour of concrete filled steel tubular columns under axial compressive load, part 2: test results on rectangular columns. Abstracts of the Annual Convention of the Architectural Institute of Japan737-8.

Broderick, B.M., Elnashai, A.S., (1996). Seismic response of composite frames - I. Response criteria and input motion. Engineering Structures 18:696-706.

Cassiano, D., D'Aniello, M., Rebelo, C., Landolfo, R., Da Silva, L.S., (2016). Influence of Seismic design rules on the robustness of steel moment resisting frames. Steel and Composite Structures 21:479-500.

Castro, J.M., Elghazouli, A.Y., Izzuddin, B.A., (2007). Assessment of effective slab widths in composite beams. Journal of Constructional Steel Research 63:1317-1327.

Castro, J.M., Elghazouli, A.Y., Izzuddin, B.A., (2008). Performance assessment of composite moment-resisting frames. 14th World Conference on Earthquake Engineering.

Chen, S., Jia, Y., (2008). Required and available moment redistribution of continuous steel-concrete composite beams. Journal of Constructional Steel Research 64:167-175. 
Choi, K.K., Xiao, Y., (2010). Analytical Studies of Concrete-Filled Circular Steel Tubes under Axial Compression. Journal of Structural Engineering 136:565-573.

Della Corte, G., De Matteis, G., Landolfo, R., (2000). Influence of connection modelling on seismic response of moment resisting steel frames. Moment resistant connections of steel frames in seismic areas - Design and reliability485-512.

Di Sarno, L., Pecce, M.R., (2007). Performance-based assessment of steel and concrete composite frames. 5th International Conference on Advances in Steel Structures, ICASS 20073.

Duan, X.N., Chandler, A.M., (1995). Seismic torsional response and design procedures for a class of setback frame buildings. Earthquake Engineering \& Structural Dynamics 24:761-777.

Elghazouli, A.Y., Castro, J.M., Izzuddin, B.A., (2008). Seismic performance of composite moment-resisting frames. Engineering Structures 30:1802-1819.

Elnashai, A.S., Broderick, B.M., (1996). Seismic response of composite frames - II. Calculation of behaviour factors. Engineering Structures 18:707-723.

Elnashai, A.S., Mwafy, A.M., (2002). Overstrength and force reduction factors of multistorey reinforced-concrete buildings. The structural design of tall buildings 11:329-351.

Elnashai, A.S., Luigi, D., (2015). Fundamentals of earthquake engineering: from source to fragility. John Wiley \& Sons.

EN 1993-1-1, (2005). Eurocode 3. Design of steel structures. General rules and rules for buildings. CEN.

EN 1994-1-1, (2004). Eurocode 4: Design of composite steel and concrete structures - Part 1-1: General rules and rules for buildings. European Committee for Standardization 3:33-38.

EN 1998-1, (2004). Eurocode 8: Design of structures for earthquake resistance-Part 1: General rules, seismic actions and rules for buildings. European Committee for Normalization, Brussels 2005.

Fazaulnizam, M., Shamsudin, B., (2014). Analytical Tool for Modeling the Cyclic Behaviour of Extended End-Plate.

FEMA P-695 (2009). Quantification of building seismic performance factors. Federal Emergency Management Agency, Washington, D.C.

Ferraioli, M., Lavino, A., Mandara, A., (2014). Behaviour factor of code-designed steel moment-resisting frames. International Journal of Steel Structures 14:243-254.

Filippou, F.C., Popov, E.P., Bertero, V.V., (1983). Effects of Bond Deterioration on Hysteretic Behaviour of Reinforced Concrete Joints. Report to the National Science Foundation. Earthquake Engineering Research Center1-212.

G. Monti, C. Nuti, S.S., (1996). CYRUS: CYclic Response of Upgraded Sections. A program for the analysis of retrofitted or repaired sections under biaxial cyclic loading including buckling of rebars.

Hajjar, J.F., Schiller, P.H., Molodan, A., (1998). A distributed plasticity model for concrete-filled steel tube beam-columns with interlayer slip. Engineering Structures 20:663-676.

Han, L.H., Wang, W. Da, Zhao, X.L., (2008). Behaviour of steel beam to concrete-filled SHS column frames: Finite element model and verifications. Engineering Structures 30:1647-1658.

Han, L.H., Wang, W. Da, Tao, Z., (2011). Performance of circular CFST column to steel beam frames under lateral cyclic loading. Journal of Constructional Steel Research 67:876-890.

Jain, S.K., Navin, R., (2002). Seismic Overstrength in Reinforced Concrete Frames. Journal of Structural Engineering 121:580585.

Jaspart, J.P., Weynand, K., (2016). Design of joints in steel and composite structures. Design of Joints in Steel and Composite Structures1-388.

Jianguo, N., Yuan, H., Weijian, Y., Jiansheng, F., (2012). Seismic behavior of CFRSTC composite frames considering slab effects. Journal of Constructional Steel Research 68:165-175.

Karavasilis, T.L., Bazeos, N., Beskos, D.E., (2008). Seismic response of plane steel MRF with setbacks: Estimation of inelastic deformation demands. Journal of Constructional Steel Research 64:644-654.

Kim, J., Choi, H., (2005). Response modification factors of chevron-braced frames. Engineering Structures 27:285-300. 
Le-Trung, K., Lee, K., Lee, J., Lee, D.H., (2012). Evaluation of seismic behaviour of steel special moment frame buildings with vertical irregularities. Structural Design of Tall and Special Buildings 21:215-232.

Li, B., Wang, J., Baniotopoulos, C.C., Yang, J., Hu, Y., (2019). Seismic design and pseudo-dynamic tests of blind-bolted CFT frames with buckling-restrained braces. Journal of Constructional Steel Research105857.

Li, B., Wang, J., Yang, J., Pan, X., Baniotopoulos, C.C., (2020). Pseudo-dynamic response and analytical evaluation of blind bolted CFT frames with BRBs. Journal of Constructional Steel Research 166:105744.

Louzai, A., Abed, A., (2015). Evaluation of the seismic behavior factor of reinforced concrete frame structures based on comparative analysis between non-linear static pushover and incremental dynamic analyses. Bulletin of Earthquake Engineering 13:1773-1793.

Martinez-Rueda, J.E., Elnashai, A.S., (1997). Confined concrete model under cyclic load. Materials and Structures 30:139-147.

Menegotto, M., Pinto, P.E., (1973). Method of Analysis for Cyclically Loaded R. C. Plane Frames Including Changes in Geometry and Non-Elastic Behavior of Elements under Combined Normal Force and Bending. proceedings of IABSE Symposium on Resistance and Ultimate Deformability of Structures Acted on by Well Defined Loads15-22.

Michalis, F., Dimitrios, V., Manolis, P., (2006). Evaluation of the influence of vertical irregularities on the seismic performance of a nine-storey steel frame. Earthquake Engineering and Structural Dynamics 35:1489-1509.

Miranda, E., Bertero, V. V., (1994). Evaluation of Strength Reduction Factors for Earthquake-Resistant Design. Earthquake Spectra 10:357-379.

Mitchell, D., Paultre, P., (2010). Ductility and overstrength in seismic design of reinforced concrete structures. Canadian Journal of Civil Engineering 21:1049-1060.

Monti, G., Nuti, C., (1992). Nonlinear Cyclic Behavior of Reinforcing Bars Including Buckling. Journal of Structural Engineering 118:3268-3284.

Mwafy, A.M., Elnashai, A.S., (2001). Static pushover versus dynamic collapse analysis of RC buildings. Engineering Structures 23:407-424.

Mwafy, A.M., (2001). Seismic performance of code-designed RC buildings. Department of Civil and Environmental Engineering. University of London.

Newmark, N., Hall, W., (1982). Earthquake Spectra and Design. EERI Monographs103.

Nogueiro, P., Da Silva, L.S., Bento, R., Simões, R., (2009). Calibration of model parameters for the cyclic response of end-plate beam-to-column steel-concrete composite joints. Steel and Composite Structures 9:39-58.

Park, R., (1988). Ductility evaluation from laboratory and analytical testing. Proceedings of the 9th world conference on earthquake engineering, Tokyo-Kyoto, Japan, Vol. 8pp. 605-616.

Park, R., (1996). Explicit incorporation of element and structure overstrength in the design process. Proceedings of the 11th WCEE. IAEE, Acapulco, Mexico, Paper.

Pecce, M., Amadio, C., Rossi, F., Rinaldin, G., (2012). Non-Linear Behaviour of Steel-Concrete Composite Moment Resisting Frames. 15th World Conference on Earthquake Engineering.

PEER, (2014). Pacific Earthquake Engineering Research Center (PEER). Pacific Earthquake Engineering Research Center.

Perea, T., (2010). Concrete-Filled Steel Tube Columns and Beam-Columns.

Pirizadeh, M., Shakib, H., (2013). Probabilistic seismic performance evaluation of non-geometric vertically irregular steel buildings. Journal of Constructional Steel Research 82:88-98.

Pirizadeh, M., Shakib, H., (2019). On a Reliability-Based Method to Improve the Seismic Performance of Midrise Steel Moment Resisting Frame Setback Buildings. International Journal of Steel Structures 19:58-70.

Schneider, S.P., (1998). Axially Loaded Concrete-Filled Steel Tubes. Journal of Structural Engineering 124:1125-1138.

SEAOC, (1999). Recommended lateral force requirements and commentary. Structural Engineers Association of California, Sacramento, CA.

Seismosoft, (2013). Seismomatch v2. 1-A computer program for spectrum matching of earthquake records. 
Seismosoft, (2016). SeismoStruct A computer program for static and dynamic nonlinear analysis of framed structures $\vee 7.0$.

Shahrooz, B.M., Pantazopoulou, S.J., Chern, S.P., (1993). Modeling slab contribution in frame connections. Journal of Structural Engineering 118:2475-2494.

Shahrooz, B.M., Moehle, J.P., (2007). Seismic Response and Design of Setback Buildings. Journal of Structural Engineering 116:1423-1439.

Shakib, H., Pirizadeh, M., (2013). Probabilistic Seismic Performance Assessment of Setback Buildings under Bidirectional Excitation. Journal of Structural Engineering 140:04013061.

Shams, M., Saadeghvaziri, M.A., (1997). State of the art of concrete-filled steel tubular columns. ACI Structural Journal 94:558571.

Shanmugam, N.E., Lakshmi, B., (2001). State of the art report on steel-concrete composite columns. Journal of Constructional Steel Research 57:1041-1080.

Simoes, R., da Silva, L.S., Cruz, P.J.S., (2001). Cyclic behaviour of end-plate beam-to-column composite joints. Steel and Composite Structures 1:355-376.

Susantha, K.A.S., Ge, H., Usami, T., (2001). Uniaxial stress-strain relationship of concrete confined by various shaped steel tubes. Engineering Structures 23:1331-1347.

Tartaglia, R., D’Aniello, M., Di Lorenzo, G., De Martino, A., (2018). Influence of EC8 rules on p-delta effects on the design and response of steel MRF. Ingegneria Sismica 35:104-120.

Tena-Colunga, A., (2004). Evaluation of the seismic response of slender, setback RC moment-resisting frame buildings designed according to the seismic guidelines of a modern building code. 13th World Conference on Earthquake EngineeringPaper No. 2027.

Tenchini, A., D’Aniello, M., Rebelo, C., Landolfo, R., Da Silva, L.S., Lima, L., (2014). Seismic performance of dual-steel moment resisting frames. Journal of Constructional Steel Research 101:437-454.

Thai, H.T., Kim, S.E., (2011). Nonlinear inelastic analysis of concrete-filled steel tubular frames. Journal of Constructional Steel Research 67:1797-1805.

Thermou, G.E., Elnashai, A.S., Plumier, A., Done, C., (2004). Seismic design and performance of composite frames. Journal of Constructional Steel Research 60:31-57.

Tomii, M., Yoshimura, K., Morishita, Y., (1977). Experimental Studies on Concrete-Filled Steel Tubular Stub Columns Under Concentric Loading. International Colloquium on Stability of Structures Under Static and Dynamic Loads, pp. 718-741.

Tomii, M., Kenji, S., (1979). Elasto-plastic behavior of concrete filled square steel tubular beam-columns. Transactions of the Architectural Institute of Japan 280:111-122.

UBC, (1997). Uniform building code. International Conference of Building Officials, Whittier, CA.

Uy, B., (2001). Strength of short concrete filled high strength steel box columns. Journal of Constructional Steel Research 57:113-134.

Vamvatsikos, D., Cornell, C.A., (2005). Direct estimation of the seismic demand and capacity of MDOF systems through Incremental Dynamic Analysis of an SDOF approximation. Journal of Structural Engineering 131:589-599.

Victor, G., Federico, M.M., (2002). Ductility of seismic resistant steel structures-Spon Press.

Wang, W. Da, Han, L.H., Zhao, X.L., (2009). Analytical behavior of frames with steel beams to concrete-filled steel tubular column. Journal of Constructional Steel Research 65:497-508.

Wang, J., Li, B., Wang, D., Zhao, C., (2017). Cyclic testing of steel beam blind bolted to CFST column composite frames with SBTD concrete slabs. Engineering Structures 148:293-311.

Whittaker, A., Hart, G., Rojahn, C., (1999). Seismic response modification factors. Journal of Structural Engineering 125:438444.

Xiao, Y., Wu, H., (2000). Compressive behavior of concrete confined by carbon fiber composite jackets. Journal of materials in civil engineering 12:139-146. 
Xu, J.J., Chen, Z.P., Xue, J.Y., Chen, Y. liang, Zhang, J.T., (2017). Simulation of seismic behavior of square recycled aggregate concrete - filled steel tubular columns. Construction and Building Materials 149:553-566.

Yahmi, D., Branci, T., Bouchair, A., Fournely, E., (2017). Evaluation of behaviour factors of steel moment-resisting frames using standard pushover method. Procedia Engineering 199:397-403.

Zahrah, H., (1984). Earthquake energy absorption in SDOF structures. Journal of Structural Engineering 110:1757-1772. 